\title{
Employment Vulnerability and Earnings in Urban West Africa
}

\author{
Philippe Bocquier ${ }^{\star}$ Christophe J. Nordman ${ }^{*}$ Aude Vescovo
}

October 2009

\begin{abstract}
:
In this article, we develop indicators of vulnerability in employment in seven economic capitals of West Africa (Abidjan, Bamako, Cotonou, Dakar, Lome, Niamey, and Ouagadougou) and study their links with individual incomes from the main job. We draw on data from the 1-2-3 Surveys in 2002-2003 to make a cross-country comparison using rigorously the same variables and methodology for each country. The theory of compensating differentials states that workers may receive pecuniary compensation commensurate with the strenuous or hazardous nature of their tasks or adverse working conditions. Our interpretation of the link between employment status and incomes draws on these developments, applying them to both working conditions themselves and more broadly to vulnerability in employment. The main tested assumption is that high levels of employment vulnerability could be compensated by greater earnings. Following recent work by Fernandez and Nordman (2009), we allow for individual and job characteristics (the latter being used to construct the composite index of vulnerability) to be differentially valued for conditionally high and low income earners.

Our composite index of employment vulnerability indicates that $85 \%$ of the private sector workers in all the economic capitals studied are vulnerable on the basis of at least one criterion. The results show that the average impact of vulnerability on earnings is generally negative for an average level of vulnerability. In the formal private sector of the West African cities, losses of income due to vulnerability are lower for high levels of vulnerability, but do not translate into gains. In the informal sector, however, the average predicted income for a high vulnerability level is higher than the average predicted income for a low vulnerability level. The assumption that average gains may compensate for a certain level of vulnerability is thus confirmed in the informal sector. Quantile earnings regressions show that the impact of vulnerability on earnings is not uniform, particularly in the informal sector where the marginal impact of vulnerability is often positive for higher deciles of the conditional earnings distribution. Consequently, even for average levels of vulnerability, premium pay is found for workers at the top of the distribution. Lastly, we show that the different aspects of vulnerability have diverse impacts on earnings. While there is no compensation for contractual insecurity and itinerant and solitary jobs, visible underemployment generally has a positive impact on the average incomes of workers in these West African cities.
\end{abstract}

Key words: vulnerability, working conditions, compensating differentials, earnings, informal sector, quantile regressions, West Africa

JEL Classification: J24, J31, O12

\footnotetext{
- We gratefully acknowledge valuable comments from participants at the DIAL workshop on labour markets in Africa (IRD, November 2007, Paris), at the "International Seminar on the Informal Sector in Africa" (SISIA, AFRISTAT, October 2008, Bamako), at the Center for the Study of African Economies Annual Conference (March 2009, University of Oxford), at the Fourth IZA / World Bank conference on "Employment and Development" (May 2009, Bonn), and at the workshop on "Social Welfare in Africa: Education, Employment and Public Programs" (September 2009, Brunel University, London). The usual disclaimers apply.

- University of the Witwatersrand, Johannesburg, South Africa; e-mail: philippe.bocquier@gmail.com

* IRD, DIAL, 4 rue d'Enghien 75010, Paris, France (corresponding author); e-mail: nordman@dial.prd.fr

\# IRD, Centre de Recherche Appliquée CERA-AFRISTAT; e-mail: aude.vescovo@afristat.org
} 


\title{
Vulnérabilité au travail et revenus en Afrique de l'Ouest urbaine*
}

\author{
Philippe Bocquier \\ Christophe J. Nordman* \\ Aude Vescovo
}

October 2009

\section{Résumé:}

Dans cet article, nous construisons des indicateurs de la vulnérabilité au travail dans sept capitales économiques d'Afrique de l'Ouest (Abidjan, Bamako, Cotonou, Dakar, Lomé, Niamey, Ouagadougou) et étudions leurs liens avec les revenus individuels de l'activité principale. Selon la théorie des salaires compensatoires, les travailleurs pourraient recevoir des compensations pécuniaires à hauteur de la pénibilité de leur tâche ou de leurs conditions de travail. Notre interprétation du lien entre le statut dans l'emploi et le revenu s'inspire de ces développements, en les appliquant non seulement aux conditions de travail proprement dites, mais plus largement à la vulnérabilité dans l'emploi (précarité contractuelle, conditions d'exercice, sous-emploi, emploi de secours inadapté aux caractéristiques individuelles). Notre indicateur composite de la vulnérabilité dans l'emploi révèle que $85 \%$ des travailleurs des secteurs privés de l'ensemble des capitales économiques étudiées sont vulnérables selon au moins un de nos critères de vulnérabilité (sur huit critères). L'effet moyen de la vulnérabilité sur les gains est généralement négatif pour un niveau moyen de vulnérabilité. Dans le secteur privé formel, les pertes de revenu causées par la vulnérabilité diminuent pour des hauts niveaux de vulnérabilité, mais ne se transforment pas en gains. Dans le secteur informel en revanche, le revenu prédit moyen pour une vulnérabilité élevée est supérieur à ce revenu pour une vulnérabilité faible. L'hypothèse que les gains moyens peuvent compenser un certain niveau de vulnérabilité est ainsi vérifiée dans le secteur informel. Des régressions de quantiles mettent en évidence que l'impact de la vulnérabilité sur les gains n'est pas uniforme, en particulier dans le secteur informel où l'effet marginal de la vulnérabilité est souvent positif pour les déciles supérieurs de la distribution conditionnelle des gains. Ainsi, même pour des niveaux moyens de vulnérabilité, la compensation salariale existe pour les travailleurs dépendants du haut de la distribution, probablement grâce à leur pouvoir de négociation supérieur. De même, un travailleur indépendant du haut de la distribution des gains pourrait réaliser plus sereinement des arbitrages entre conditions d'emploi et gains. Finalement, nous montrons que les différents aspects de la vulnérabilité ont des impacts distincts sur les revenus. Alors que la précarité contractuelle et le caractère ambulant et solitaire de l'emploi ne sont pas compensés, le sous-emploi visible a généralement un effet positif sur les gains moyens des travailleurs de ces grandes villes ouest-africaines.

Mot-clefs: vulnérabilité, conditions de travail, différentiels compensatoires, revenus, secteur informel, quantiles, Afrique de l'Ouest

JEL Classification: J24, J31, O12

\footnotetext{
- Nous remercions les participants au workshop de DIAL sur les marchés du travail en Afrique (IRD, novembre 2007, Paris), au « Séminaire International sur le Secteur Informel en Afrique 》 (SISIA, AFRISTAT, Octobre 2008, Bamako), à la conférence annuelle du CSAE sur l'Afrique (mars 2009, University of Oxford) et à la $4^{\mathrm{e}}$ conférence IZA / Banque mondiale (mai 2009, Bonn) pour leurs remarques constructives sur une première version de cet article.

- University of the Witwatersrand, Johannesburg, South Africa; e-mail: philippe.bocquier@gmail.com

* IRD, DIAL, 4 rue d'Enghien 75010, Paris, France (corresponding author); e-mail: nordman@dial.prd.fr

\# IRD, Centre de Recherche Appliquée CERA-AFRISTAT; e-mail: aude.vescovo@afristat.org
} 


\section{Introduction}

Urban labour market workers in sub-Saharan Africa work in often highly insecure conditions. The World Bank's 2000 report states that job insecurity is a major concern among poor workers and job instability is a leading cause and expression of poverty.

One of the main focuses of studies on labour markets in sub-Saharan Africa is the institutional segmentation between formal and informal sectors (Maloney, 2004). Informal work is defined from the point of view of the firm, worker or line of business depending on the policy aims. The 1993 System of National Accounts (SNA93) - comprising a set of international standards designed to establish a framework for the production of statistics on national accounts - defines a distinction at firm level based on statistical or tax registration criteria and keeping written accounts.

Yet this distinction serves no purpose when it comes to capturing individuals' working conditions, especially employment vulnerability. By vulnerability, we mean how hard it is for individuals to manage the risks or cope with the losses and costs associated with the occurrence of risky events or situations. ${ }^{1}$ For example, the vulnerability of workers can be seen, among other things, in terms of contract insecurity (unstable remuneration and no written contract), adverse working conditions and, more generally, the worker's high level of exposure to risks concerning her job. Firm or business vulnerability criteria (activity sectors, business size and institutional sectors) are not used here since they reflect interfirm dualism rather than interindividual dualism. Vulnerable workers can be found in all sorts of formal and informal private firms, but also in administrations and public and semi-public corporations. A good many vulnerable workers work in the formal private sector, as per the SNA93 definition of the term. This paper focuses solely on the private sector (formal and informal businesses), based on the assumption that vulnerability is driven by different mechanisms in the public and private sectors.

We build employment vulnerability indicators and study their links with earned income. The theory of compensating differentials formalised in the $1980 \mathrm{~s}^{2}$, although its precepts date back to Adam Smith, ${ }^{3}$ states that workers may receive pecuniary compensation commensurate

\footnotetext{
${ }^{1}$ The still-developing economic literature on vulnerability includes a range of definitions of this notion. Wilson and Ramphele (1989) define it as the risk of destitution, famine or death. The concept of vulnerability moved forwards recently with Amartya Sen's capability approach (1992 and 1999). Cheli and Lemmi (1995) consequently propose a fuzzy and relative approach to vulnerability, which enables them to define an "exposure to the risk of poverty" notion. The vulnerability concept used in Qizilbash (2003 and 2006) is an individual's distance from a definite, unambiguous state of poverty. The closer the individual is to being definitely poor, the greater his vulnerability. In Dubois and Rousseau (2001), vulnerability is a person's own structure of "capabilities" that enables that person to replace (or not) one capability with another in the event of an exogenous shock. The loss of a job would therefore have a greater impact on an individual with less leeway to work in different occupations and a low level of economic and social capital. We refer in this article to a notion similar to that developed by Cheli and Lemmi (1995) and Qizilbash (2006), since it remains vague about the exact level of the state of poverty and also about its multidimensional aspect.

${ }^{2}$ See Brown (1980), Rosen (1986), and Murphy and Topel (1987).

3 Adam Smith (1776) identified five circumstances to explain why it is not the wage that is the balancing factor among different jobs on a competitive market ("perfect liberty"), but all the pros and cons of a job: "The five following are the principal circumstances which, so far as I have been able to observe, make up for a small pecuniary
} 
with the strenuous or hazardous nature of their tasks or adverse working conditions. In the developed countries, for example, it has been observed that physically hazardous and highly strenuous jobs are often better paid than less strenuous or hazardous jobs. ${ }^{4}$ In our approach, we do not cover health hazards as such since the data used do not take in this aspect, except in terms of having dedicated business premises.

Our interpretation of the link between vulnerability and income draws on developments in the theory of compensating differentials, applying them to both working conditions and employment vulnerability. Hence our working assumption is that, other things being equal, workers classified as vulnerable may be better paid than more stable, steady workers classed as less vulnerable. Should this be the case, an incentive should be found for certain individuals to hold a vulnerable job, especially if the medium- or long-run advantage associated with stable jobs is not valued by households force into short-term income management. These households should prefer higher, immediate earnings - even from a vulnerable job - to stable earnings over a longer period.

Our analysis subsequently takes a more qualitative approach, conducting a principal component factor analysis on the different aspects of the vulnerability phenomenon. The main components obtained, which represent the different qualitative facets of vulnerability (contractual insecurity, working conditions, underemployment and stopgap jobs mismatched with the individual's characteristics), are then used as vulnerability variables.

The question of vulnerability determinants and the link between vulnerability and remuneration raises a certain number of methodological problems that this paper endeavours to solve. First of all, there is the existence of labour market entry selection. A second sample selection concerns the individual's sector allocation (public, formal private or informal private). Thirdly, there is a likelihood of vulnerability being endogenous in the earnings equations. Vulnerability is endogenous if the individuals' unobservable characteristics are correlated with both their level of vulnerability and their level of earnings. It is important to take these effects into account, since they can produce biases such as an overestimation of the negative (positive) impact of vulnerability on individual earnings if, for example, unobservable characteristics such as low worker motivation or "laziness" (or conversely worker perseverance) are positively correlated with the probability of obtaining a vulnerable job while simultaneously being negatively (positively) correlated with earnings.

Our analysis also takes a distributional approach. Our second working assumption is that vulnerability can have a different effect on income depending on the worker's relative position on the remuneration scale. Hence, for equal observable characteristics, a worker at the lower tail

gain in some employments, and counter-balance a great one in others: first, the agreeableness or disagreeableness of the employments themselves; second, the easiness and cheapness, or the difficulty and expense of learning them; third, the constancy or inconstancy of employment in them; fourth, the small or great trust which must be reposed in those who exercise them; and fifthly, the probability or improbability of success in them." (Book I, Chap. X, part I)

${ }^{4}$ However, there is not a great deal of empirical evidence to support this point. See, in particular, Poggi (2007) and Fernandez and Nordman (2009). 
of the earnings distribution (poor) could be penalised in monetary terms by her vulnerability whereas a worker at the top of the distribution (wealthy) might not be penalised and may well receive pecuniary compensation in a vulnerable job. These different pay mechanisms depending on remuneration scale position could be due to bargaining power differences and labour market imbalances. In the first case, greater bargaining power for the wealthy would enable a worker at the upper tail of the earnings distribution to secure higher pay for the vulnerability of her job. Conversely, workers at the bottom of the earnings distribution might be more forceful in negotiations for premium pay if they are seeking to secure a living wage. Compensation for vulnerability would therefore decrease the further the worker moved from a minimum subsistence income. In the case of the existence of labour market imbalances, the employer's capacity to provide financial compensation for adverse working conditions might also differ depending on the type of imbalances found in certain market segments, in particular along the length of the skills and hence earnings distribution. For example, it would make sense to find that employers in segments where labour supply far outstrips demand are reluctant to pay workers more for adverse working conditions. These hypotheses, which assume that the effect of vulnerability on earnings differs depending on the position in the earnings distribution, are tested using quantile regressions.

Our composite index of employment vulnerability indicates that $85 \%$ of the private sector workers in all the economic capitals studied are vulnerable on the basis of at least one criterion. The econometric results show that the average impact of vulnerability on earnings is generally negative for an average level of vulnerability. In the informal sector, however, the average predicted income for a high vulnerability level is higher than the average predicted income for a low vulnerability level. The assumption that average gains may compensate for a certain level of vulnerability is thus confirmed in the informal sector. Quantile earnings regressions show that the impact of vulnerability on earnings is not uniform, particularly in the informal sector where the marginal impact of vulnerability is often positive for higher deciles of the conditional earnings distribution. Lastly, we show that the different aspects of vulnerability have diverse impacts on earnings.

The remainder of the paper is structured as follows. In Section 2, we briefly study the theoretical arguments underlying the existence of compensating differentials and highlight the theory's implications for our case study. In Section 3, we present the data drawn from the 1-2-3 Surveys of the West African economic capitals and the construction of certain key variables for our analyses. Section 4 details our econometric models. The results of these analyses are discussed in Section 5 and our conclusions put forward in Section 6. 


\section{The theory of compensating differentials}

There is a long history of economic research into the forces that narrow or widen wage differentials between individuals. The first models focused on competitive markets where they found wage premiums compensating non-pecuniary job attributes, such as working conditions, and differences in job stability across industries (Brown, 1980; Rosen, 1086; Murphy and Topel, 1987). Most of the authors acknowledge that when job characteristics (other than wages) enter into players' labour market decisions (firms and workers), then the market balance is due to the equalisation of workers' utilities rather than their wages.

Rosen (1986) posits that the reasoning behind this is to be found in a simple supply and demand structure. Labour supply decisions are based on a trade-off between earned income (wages) and the cost of doing the job (stress, repetition, production deadlines, etc.) such that, at optimum, wage differences correspond to the marginal rate of substitution between consumption and working conditions. ${ }^{5}$ Labour demand decisions by firms are based on a tradeoff between the necessity of paying the workers compensation commensurate with the strenuous or hazardous nature of their task and the need to improve the working conditions offered.

Hence, under the assumption of homogeneous individuals and heterogeneous work environments, wages differ between workers such that they all obtain the same utility. To encourage workers to accept more adverse working conditions, firms therefore have to offer higher wages. This is the basic idea behind the theory of compensating wage differentials. Lifting the assumption of homogeneous individuals necessarily introduces a great deal of uncertainty as to the existence of compensation for working conditions when it is observed at the midpoint of the worker distribution. It could prove necessary to divide the population observed into more homogeneous groups, for example by using a conditional wage quantile derived from quantile regressions, so as to reduce the noise created by the presence of individual heterogeneity in the estimation of the compensating differential.

More recently, non-competitive theories have argued that wage deviations between apparently identical individuals tend more to reflect non-compensating differentials, such as the workers' relative bargaining power (Daniel and Sofer, 1998; Manning, 2003) and the existence of efficiency wages. ${ }^{6}$ Other recent hypotheses have pointed up the existence of information asymmetries, which allegedly increase the friction in the labour supply-demand match (Hwang, Mortensen and Reed, 1998), and the existence of factor productivity differences between firms (Burdett and Mortensen, 1998; Pissarides, 2000; Mortensen, 2003).

\footnotetext{
${ }^{5}$ Given utility $U(C, D)$, where $C$ is the worker's consumption and $D$ adverse working conditions, the worker maximises her utility under constraint $C=W(D)$, implying that $W^{\prime}(D)=U_{D} / U_{C}$.

${ }^{6}$ See Katz (1986) for a review of the efficiency wage theories, Lindbeck and Snower (1989) for a review of insideroutsider models (labour market segmentation theory), and Akerlof and Yellen (1990) for an extended version of efficiency wage theory.
} 
Although some empirical studies focus on the relationship between wage structure and non-monetary job satisfaction, ${ }^{7}$ there is a patent paucity of research into the link between compensating differentials and observed job attributes, especially when it comes to distributional approaches. In the first study of this kind, Fernandez and Nordman (2009) show that the compensating differential actually differs depending on the worker's relative position in the earnings distribution. For example, pecuniary compensation for adverse working conditions could well be overestimated if the most capable (or resistant) workers are selected for employment statuses where these attributes are more commonplace. Moreover, given the assumption that the most capable individuals are also the most likely to receive efficiency wages, or to have a certain amount of bargaining power, working conditions could well have less to do with the wage-setting process for these individuals than for other workers without these characteristics. More generally, workers could also find it easier to ask for premiums for adverse working conditions when the demand for labour exceeds the available manpower, creating a labour market imbalance that probably varies along the earnings distribution.

In the following, we present the approach used to characterise the working conditions of individuals working in the private sector in the West African economic capitals (Section 3). Our study concentrates on the issue of employment vulnerability found, for example, in insecure employment contracts, adverse working conditions and, more generally, greater worker exposure to work-related risks. We first take a quantitative approach (what is the effect of vulnerability on average earnings?) and then a distributional approach (do any compensating phenomena found differ along the distribution of individual earnings?). Lastly, a qualitative analysis separates out the different facets of vulnerability and identifies which aspects may be compensated for by earnings.

\section{Data and definition of vulnerability}

\subsection{The samples used}

The data used are taken from phase 1 of the 1-2-3 Surveys conducted by the PARSTAT regional statistical assistance programme for multilateral monitoring set up by the WAEMU Commission. Data collection took place in the following economic capitals in 2001: Niamey (Niger), Ouagadougou (Burkina Faso), Dakar (Senegal), Bamako (Mali), Cotonou (Benin), Lome (Togo) and Abidjan (Côte d'Ivoire). ${ }^{8}$

The sample was first of all restricted to all working-age individuals as defined by the International Labour Organization standards, i.e. 15 years old and over. We then reduced the

\footnotetext{
${ }^{7}$ The studies on this issue often generate contradictory findings. See, for example, French and Dunlap (1998), Groot and Maassen van den Brink (1998), Lanfranchi et al. (2002), Magnani (2002), Clark and Senik (2006), Bockerman and Ilmakunnas (2006), and Poggi (2007).

${ }^{8}$ See Brilleau, Ouedraogo and Roubaud (2005) for details on the survey methodology and Kuepie, Nordman and Roubaud (2009) for first econometric analyses of the data collected.
} 
samples further to individuals aged 15 and over with at least five years of potential labour market experience in order to take account of workers' employment histories and thereby understand the longitudinal aspects of vulnerability. Potential experience is defined as the individual's age minus the number of years of education and the six years theoretically preceding the start of school. The five-year potential experience span is broad enough to circumvent the problem of date measurement errors (end of education and end of previous job) and narrow enough to prevent the samples from being too small.

The total sample (seven cities) is thereby reduced from 58,385 individuals aged 15 years and over to 50,772 individuals aged 15 years and over with five years or more of potential experience, and from 33,390 employed workers aged 15 and over to 32,314 employed workers aged 15 and over with five years or more of potential experience. Among these employed workers, we are only interested in formal and informal private sector workers. The formal private sector regression samples range from 302 to 950 workers (in Lome and Dakar) depending on the country, with a small minority of self-employed workers. The informal private sector regression samples range from 2,230 to 3,492 workers (in Niamey and Dakar), with a majority of selfemployed workers. The sample population details are presented in Table 1 in the appendix.

\subsection{Construction of the vulnerability variables}

Our approach consists of using a number of employment status indicators for the individual (main and second job), which we believe best sum up the multifaceted nature of vulnerability in the main job. Business or production unit criteria (activity sector, business size and institutional sector) are not used as they reflect interfirm rather than interworker dualism. Worker vulnerability is therefore defined here by employment differentiation criteria. Nine dichotomous variables are built corresponding to different aspects of vulnerability (see their descriptive statistics in Table 2 in the appendix).

The first variable, called contractual insecurity, concerns the informal nature of the contract. This variable equals 1 if the individual has no written contract or does not receive a payslip. It equals 0 if the individual has both a payslip and a contract. It is not defined for selfemployed workers, to whom it does not apply. Where workers have a contract, we make no distinction between those with a fixed-term contract and those with an open-ended contract.

The second variable concerns independent workers only. It is equal to 1 if an independent worker has no employees, wage-earning or otherwise. Self-employed professionals working alone in intellectual professions are not considered to be vulnerable.'

Adverse working conditions are assessed in terms of the place or premises where the individual works. This variable is equal to 1 if the individual's main job is itinerant, worked from a makeshift or fixed street pitch, at the customer's home or from the individual's own home without having a dedicated set-up for the job. It is equal to 0 if the individual works from his

\footnotetext{
${ }^{9}$ Such as computer engineers, doctors, notaries and lawyers.
} 
vehicle, from home with a dedicated set-up for the job, in a public market or on business premises (including fields in the case of urban market gardening). Where certain jobs do not require premises even though they are not physically strenuous, the existence of premises, an office or a surgery is still taken as an indication of stability and non-adverse working conditions. To exclude all the intellectual professions from vulnerability in terms of working conditions would be tantamount to defining a vulnerable worker profile (comprising mainly roving street vendors and servants versus the intellectual professions). This would be inconsistent with the analysis of the many forms of vulnerability and its link with earnings.

Casual labour is a source of vulnerability. Pagès (2003) states that vulnerability in employment "is polysemous and covers as much the different forms of underemployment as the lack of socioeconomic security at work associated more with institutional variables (employment contracts, compliance with labour code, etc.) and their time-related factors (casual and unstable employment)." So even if a job is protected or worked in good conditions, the casual nature of the employment means that this protection is not guaranteed over time and that the risk of visible underemployment is high. Therefore, a casual job is deemed a criterion of vulnerability. The casual labour variable is equal to 1 if the individual is a piece-rate, day or seasonal worker. It is equal to 0 if the individual has a steady job.

The unstable remuneration variable is equal to 1 if a dependent worker is not paid a fixed wage (monthly, fortnightly or weekly) or if an independent worker is not paid in the form of a fixed wage or profits (i.e. if she is paid by the day, hour, piece rate, commission, in kind or is not paid at all). This variable differs from the variable above. A worker in a steady job may be paid erratically (this is frequently found). She is then assumed to be more vulnerable since she cannot predict what her situation will be in the coming days or weeks.

Pagès (2003) defines vulnerability, among other things, as underemployment or the probability of becoming underemployed. Visible underemployment corresponds to the situation where an individual works less than the statutory working week when he would like to work more. The underemployment variable is equal to 1 if the individual works less than 35 hours and would like to work more. It is equal to 0 otherwise.

Working a second job could, in certain cases, reflect underemployment or instability in the main job. Granted, public-sector and private-sector wage earners - often seen as not being vulnerable precisely because they work in these sectors - work a second job to earn money for their retirement or their children. Yet a visibly or invisibly underemployed individual or a piecerate worker may hold down a second job to keep money coming in when they are temporarily laid off from their main job. Working a second job may be seen as a way of reducing or spreading the risks of an income loss or decrease. The second job variable is equal to 1 if the individual works a vulnerable second job, i.e. outside the public sector, in a place or premises not dedicated to this job and in a firm of less than five people, and if the number of cumulative hours worked in the two jobs is 70 hours or more a week. 
Pagès (2005) emphasises the importance of considering the dynamic aspect of vulnerability. The above employment situation impacts on the workers' capacities and behaviour (the skills-employment causality is reversed). The author measures the dynamic facet of vulnerability at work in terms of labour mobility and employment integration. Similarly, we define two dynamic vulnerability criteria.

Instability in employment is defined by a change of job without an improvement or with a drop in status in the last five years. This variable is equal to 0 if the individual is in his first job or has found a job following a period of unemployment or inactivity over the last five years. It is also equal to 0 if the individual has been in the same job for five years. Lastly, it is equal to 0 if the individual has changed job with an improvement in job status (from the point of view of socioeconomic group, reflecting upward professional mobility) in the last five years. However, it is equal to 1 when the individual has changed job in the last five years without an improvement in status (drop in or identical socioeconomic group). The adopted status hierarchy is as follows, from top to bottom: senior executives, engineers or equivalent; middle managers and supervisors, skilled and semi-skilled non-manual and manual employees; unskilled workers; apprentices and family workers. In the case of an independent-dependent worker transition, the reason for the change of job - voluntary or involuntary - is used to determine whether the transition represents an upwardly mobile professional move or not.

An unwanted job is defined as a job with which the worker is dissatisfied and which she has taken on following an involuntary departure from the previous job. Job dissatisfaction is measured by the answer to a question about the individual's aspirations (keep or change his job and, if the interviewee answers that she wants to change, for what type of job). An unwanted job is more probably occupied due to constraints and is hence mismatched with the worker's expertise, skills and preferences. A worker may be dissatisfied in her job because she is overqualified for it, because her working conditions are physically strenuous, because the hours are unsuitable for her, etc. Working an unwanted job may therefore indicate a subsistence job, a "stopgap job" taken in the hope of immediate gains.

Other potential vulnerability criteria have not been taken into account. For example, we do not create a social security variable as Pagès does (2005), since our income variable includes all welfare benefits. However, unstable remuneration or no written contract, for example, should be enough to reflect the worker's social insecurity. Membership of a union and access to in-house training are variables of interest to the vulnerability study. However, these phenomena are so rare in the capitals studied that we deem them to be negligible.

So for each employment status (dependent or independent), we define the intensity of vulnerability $I$ as the sum of the eight previously defined criteria applicable to this status. Maximum vulnerability intensity ranges from 4 to 7 depending on the city and sector. No city posts the maximum score of 8 whereby all the vulnerability criteria applicable to a status are fulfilled (Table 3). 
A dichotomous dummy variable for vulnerability, built by setting a vulnerability threshold (a minimum number of vulnerability criteria to be met to be deemed vulnerable), would have simplified our measurement. However, the effect of vulnerability on income might be nonlinear and a dichotomous dummy variable would not show this up. The fact that a worker fulfils one or two vulnerability criteria may be due to constraints imposed on her on the labour market. However, whereas a certain level of vulnerability might be imposed on the worker, it might also be chosen by the same worker who prefers to be more vulnerable for higher earnings.

\subsection{Descriptive statistics}

Contractual insecurity concerns virtually all $(97 \%)$ of the dependent workers in the informal sector (Table 2). More surprisingly, it affects half of the employees in the formal private sector: A total of $40 \%$ do not have written contracts or payslips. Similarly, 23\% of the dependent workers in the formal private sector and $60 \%$ of the dependent workers in the informal private sector do not receive a fixed wage. This implies that the distinction between formal private firms and informal private firms is not enough to analyse workers' living and working conditions, calling for a study of worker vulnerability regardless of institutional sector (formal private or informal private).

The main sources of vulnerability among independent workers in the informal sector are adverse working conditions (59\% of independent workers), in terms of no dedicated premises or workplace, and own-account employment, i.e. not having any employees $(68 \%$ of independent workers). These percentages are small in the formal private sector, where self-employed workers are largely in the minority (less than $20 \%$ in all the cities).

A total of $17 \%$ of dependent private sector workers and $14 \%$ of independent private sector workers are not at all vulnerable since they do not fulfil one single vulnerability criterion. Yet these rates mask huge differences between the formal and informal sectors. In the informal sector alone, the rates fall to $2 \%$ and $12 \%$ respectively. So $85 \%$ of the private sector workers in all the economic capitals studied are vulnerable on the basis of at least one criterion.

Chart 1a (resp. Chart 1b) shows the log of average earnings in the formal private sector (resp. informal sector) for each level of vulnerability, without any control of the workers' individual characteristics. The income curves are not linear in vulnerability intensity in either sector. For a vulnerability level of over 5, the earnings curves for the different capitals' informal sectors display different trends with sudden slope changes. These cannot be interpreted since they are based on very low observation numbers (see Table 3). Similarly, the shape of the formal private sector curves above vulnerability level 4 cannot be interpreted.

For all the cities and sectors, the earnings curves are convex around a point of inflection situated near a vulnerability intensity of 2 or 3 . It could be that the job market restricts all workers to an "incompressible" vulnerability level regardless of their aptitudes and networks. 
However, higher earnings are found at a vulnerability level of over 2 or 3 . Above this vulnerability level, then, workers should be able to negotiate premium pay for their vulnerability.

\section{Testing the existence of compensating mechanisms for vulnerability}

In a first step, the determinants of vulnerability are analysed using a simple linear model whose dependent variable is the intensity of vulnerability. ${ }^{10}$ The explanatory variables introduced are dummy variables for the individual's status in the household (1 if household head) and the institutional sector of the individual's father when the individual was 15 years old (public, formal private or informal private). These first variables are denoted $Z$. The set of control variables included in all the estimated equations $(X)$ covers gender, education (number of years of successfully completed education) and its square, potential experience and its square, religion (Christian, reference: Muslim), migratory status (rural, urban or foreign migrant, reference: native of the city studied), marital status (conjugal status, reference: widowed, divorced or single), seniority in the firm or main job and its square, and independent status (self-employed employer or own-account worker versus dependent worker).

Secondly, to test the existence of compensating wage differentials for vulnerability, we estimate the log of the hourly wage rate for the main job for each city. Included in this wage rate are benefits such as year-end bonuses, profit-sharing, paid leave, medical service benefit, social security and other bonuses, and benefits in kind such as housing, electricity and transport. It is calculated from the monthly earnings for the reference month and the number of hours worked per week.

\subsection{Quantitative approach}

We talk about a quantitative approach when we study the impact of vulnerability intensity on income. In this approach, what counts is the cumulative number of vulnerability criteria fulfilled by an individual rather than such or such a criterion.

Let $E$ be all four institutional sector categories ( $b=1$ : zero income, $b=2$ : public sector, $b=3$ : formal private sector, and $b=4$ : informal sector). Our purpose is to estimate the effect $\varphi_{h}=\left(\varphi_{1 h}, \varphi_{2 h}\right)$ of vulnerability $I$ on earnings in the formal and informal private sectors using:

$Y_{h}=\beta_{h} X+\varphi_{1 h} I+\varphi_{2 h} I^{2}+\varepsilon_{h} \quad \forall h=3.4$

\footnotetext{
${ }^{10}$ An ordered probit model is also estimated and provides comparable results.
} 
The introduction of a second-degree vulnerability intensity polynomial ${ }^{11}$ is designed to take into account any nonlinearity in the effect of vulnerability on income. $Y_{b}$ is only observed if the individual has a paid job and if sector $b$ is chosen by the individual.

Given that the labour markets in developing countries are segmented, sector entry selection may exist in addition to labour market entry selection. So a selection model is needed. We use the Lee (1983) model, an extension of the Heckman method, to estimate the earnings equation with multinomial selection. This method corrects the selection bias, by estimating:

$Y_{h}=\beta_{h} X+\varphi_{1 h} I+\varphi_{2 h} I^{2}+\lambda_{h}+\kappa_{h} \quad \forall h=3.4$

where $\lambda_{h}$, a generalisation of the inverse Mills ratio in Heckman's method, corrects the selection bias generated by the fact that belonging to sector $h$ rather than sector $k(k \neq b)$ may be due to the action of unobservable variables also associated with income. It is interpreted as the difference between the earnings of a first individual in sector $b$ and the income that would have been earned by a second individual - drawn randomly from the first equation sample (i.e. an individual who can belong to any sector) and with the same observable characteristics as the first individual - had he belonged to sector $h$.

In our model, the identifying variables $(M)$ required for the robustness of the selection model are the inverse of the dependency ratio (number of employed workers to household size), a dummy variable for whether the individual's father went to primary school, and a dummy variable for whether the individual's head of household is a woman. These variables are introduced into the selection equation (multinomial logit model with four categories for $h$ : $1 \ldots 4^{12}$ ), whence $\lambda_{b}$, but not into the earnings equation. The assumption is that these variables only influence income via sector allocation.

A second problem that needs to be solved is that the intensity of vulnerability is potentially endogenous. Unobservable characteristics may affect both the explanatory variable for vulnerability and the level of earnings. This would be case, for example, if "poor" (better) workers, a characteristic all too often unobserved in the surveys, were selected for employment statuses where vulnerability is the most widespread (see Section 2). In this case, any positive effect vulnerability might have on earnings could be under(over)estimated. Since disregarding this factor could produce non-convergent estimators of $\varphi_{h}=\left(\varphi_{1 h}, \varphi_{2 h}\right), I$ needs to be instrumented.

\footnotetext{
11 The introduction of a third-degree polynomial into the earnings equations was tested, but did not find evidence that vulnerability has a cubic effect on income. Dummy variables were also introduced for each vulnerability level to test for nonlinearity, but this made it harder to interpret the estimated coefficients.

12 The multinomial logit model's validity is based on the assumption of independence of irrelevant alternatives (IIA). There is, in principle, no reason to believe that this assumption holds, but rather to expect it to be violated if the individuals' choices are made in a "string". However, in the practical case of a first step with a view to correcting the selection bias in a second step, the violation of IIA is not problematic. Bourguignon, Fournier and Gurgand (2007) use Monte-Carlo simulations to show that the Lee model is effective even when IIA is violated.
} 
To do this, we use the control function method rather than the two-stage least squares estimator (Garen, 1984; Wooldridge, 2002). Where income is nonlinear in the potentially endogenous variable (here vulnerability intensity), this method provides more accurate estimators than the two-stage least squares method (Card, 2001). The control function method involves regressing, in a first step, the intensity of vulnerability on the individual characteristics $X$ and on the instrumental variables $Z$, not correlated with $\kappa$, the residual from the earnings equation (2), and (partially) correlated with $I$ (equation (3)). These instruments are the dummy variable for the status of the head of household and the dummy variables for the institutional sector of the individual's father. In principle, these variables do not have a direct impact on earned income since they have nothing to do with productivity, the worker's capacities or the type of job held. However, being a head of household could form an incentive to accept a more vulnerable job when faced with the urgent need to find a job to feed the family or a less vulnerable job to guarantee stability for the household.

$I=\alpha_{h} X+\gamma_{h} Z+\mu_{h} \forall h=3,4$

The estimated residual from this first linear regression, $\hat{\mu}$, is introduced as an explanatory variable, controlling for unobserved heterogeneity, into the earnings equation.

$Y_{h}=\beta_{h} X+\varphi_{1 h} I+\varphi_{2 h} I^{2}+\lambda_{h}+\hat{\mu}_{h}+\kappa_{h} \quad \forall h=3,4$

The resulting estimators of $\varphi_{b}=\left(\varphi_{1 b}, \varphi_{2 b}\right)$ are convergent if the model satisfies the classic identification conditions and if the instruments are independent of $\hat{\mu}$ and not correlated with the earnings equation residual $\kappa_{b}$.

For all the estimations, the bootstrap method (500 replications) is used to estimate the standard deviations since they are biased due to the nature of our two-stage estimations.

\subsection{Distributional approach}

The impact of vulnerability on income may differ across the earnings distribution (see Section 2). Quantile regressions are used to take into account these potential effects.

Firstly, the estimation of equation (1) is resumed using conditional quantiles, such that

$q_{\tau}\left(Y_{h} \mid X, I, I^{2}\right)=\beta_{h}(\tau) X+\varphi_{1 h}(\tau) I+\varphi_{2 h}(\tau) I^{2} \quad \forall h=3,4(5)$

where $q_{\tau}\left(Y_{h} \mid X, I, I^{2}\right)$ is the $\tau^{\text {th }}$ conditional quantile of $Y_{h}$ and where vector $\hat{\beta}_{h}(\tau)$ and the estimated coefficients $\hat{\varphi}_{1 h}(\tau)$ and $\hat{\varphi}_{2 h}(\tau)$ provide the effects of the different regressors at the $\tau$ th quantile of the earnings distribution in sector $h$.

This framework does not take selection effects into account. Whereas the control function method can also be used in the case of quantile regression, to our knowledge, no models exist that can estimate quantile regressions with multinomial selection. Moreover, this distributional approach corrects solely the supposed endogeneity of vulnerability. This is not a major drawback 
since, as we will see in Section 5, the results of the quantitative approach are not sensitive to the consideration of a possible selection effect.

\subsection{Qualitative approach}

To build a cumulative index of vulnerability intensity is to assume that all the criteria involved in vulnerability have the same weight. Is income influenced by the number of vulnerability criteria satisfied or the existence of one given vulnerability criterion? Moreover, certain vulnerability criteria (such as casual labour and unstable remuneration) are potentially collinear, invalidating the coherence of the cumulative index and introducing all the criteria into the earnings equations. We therefore put the vulnerability criteria through a principal component analysis (PCA) to extract orthogonal factor axes. PCA is conducted separately for independent workers and dependent workers. For each of these two statuses, the first four axes are taken so that all the criteria are sufficiently well represented by the axes (all contribute to at least one axis to the tune of $50 \%$ or more) and such that the variance explained by the chosen axes is approximately $60 \%$. In keeping with the method used in Jellal et al. (2008), these axes are then introduced into the earnings equations.

The axes generated by the PCA of dependent workers are not defined for independent workers (and vice versa). One way of introducing them into the earnings equation is to conduct a separate regression for each subsample of dependent and independent workers. This solution can only apply to the informal sector, but not to the formal private sector due to the small numbers involved. Another solution is to cross the factor variable with the status dummy variable. Let $D_{1}$ be the first vulnerability axis extracted by the PCA on dependent workers. The value $D_{1}$ for a dependent worker is her co-ordinate on this axis. For an independent worker, this variable is equal to zero. The two options were tested and produced very similar results, so we only present the results of crossing the factor axes with the independent or dependent status.

\section{Results}

\subsection{Quantitative approach}

\section{Determinants of vulnerability and quality of the instruments}

The instruments used to instrument vulnerability are the head of household's status and the father's institutional sector. In the formal private sector, the impact of the head of household's status is negative and significant in Ouagadougou, Dakar and Abidjan, and significantly positive in Cotonou (Table 4). In the informal sector, the impact is negative in the seven cities, but not significant in Dakar and Cotonou. The head of household could, regardless of gender (controlled for in the model), have a longer term horizon than individuals who are not heads of household. They may see things more in terms of the long run, be less drawn by 
immediate gain than a non-household-head individual of the same age who would prefer an immediate gain at the cost of a vulnerable job.

In the formal sector, the father's institutional sector does not predict the intensity of vulnerability. The father's employment in the formal private sector rather than the public sector only has a significant (negative) impact on vulnerability in Dakar and Lome. In the informal sector, the quality of the father's institutional sector instrument is better since it appears to influence vulnerability in five out of seven cases, i.e. in Lome and Abidjan. Interviewee ignorance of where the father worked and the father's employment in the informal sector play a significant and negative role in Ouagadougou, Dakar, Bamako and Cotonou. The father's employment in the formal private sector plays a significant and negative role in Dakar and Bamako and a significant and positive role in Niamey.

For each city and each sector, at least one instrument is found to have a significant effect on vulnerability, except in the formal private sectors of Niamey and Bamako. Therefore, the estimates corrected for the endogeneity of vulnerability need to be interpreted with caution in the case of these two cities' formal sectors given the inefficient instrumental variable procedure in both cases. By and large, however, note the satisfactory quality of our instruments since the condition required to correlate the instruments with the endogenous variable is satisfied.

Let's now look at the effect of vulnerability on earnings based on models (1), (2) and (4) presented in Section 4.1. Table 5 shows the marginal effects of the vulnerability indicator on earnings, calculated at the average vulnerability point. ${ }^{13}$ Regardless of whether or not the sample selection and endogeneity of vulnerability are corrected, the marginal effect of average vulnerability is negative in both sectors for all the cities except in the informal sector in Dakar, where this effect is slightly positive. In both sectors, formal and informal private, the selection correction barely alters the results. However, the vulnerability endogeneity correction alters the magnitude of the marginal effects. The marginal effect of vulnerability on earnings is already markedly negative before correcting for endogeneity. Once endogeneity is taken into account, the impact of vulnerability remains negative, but is much greater.

In the formal private sector, one additional point of vulnerability reduces income by $16 \%$ (Cotonou) to $34 \%$ (Dakar). ${ }^{14}$ In the informal sector, the marginal effect of vulnerability on earnings is smaller. If the endogeneity of vulnerability had not been taken into account, the effect of vulnerability on income would have been deemed negligible. However, once the endogeneity of vulnerability is included, it has a large impact on earnings. One additional point of vulnerability reduces income by 3\% (Cotonou) to 20\% (Abidjan). The marginal effect is positive in Dakar only. For example, if a worker's vulnerability intensity were to increase from 2 points to 3 points, her earnings would increase an average $1 \%$.

\footnotetext{
${ }^{13}$ All the regression tables are available from the authors.

${ }^{14}$ Bear in mind that caution is called for when considering the estimation corrected for endogeneity in the case of the formal sector in Bamako (37\%).
} 


\section{The convex effect of vulnerability on earnings}

These marginal effects are calculated for average vulnerability intensity. In the formal private sector, workers satisfy one in eight vulnerability criteria on average. In the informal sector, this average vulnerability point is close to 2 . Hence, if we wanted to identify any compensating effects for higher than average vulnerability levels, we would have to study the coefficients estimated for the second-degree vulnerability intensity polynomial.

Tables 6 and 7 show that, regardless of the model used, vulnerability has a negative effect on earnings in all the cities and in both institutional sectors. However, in these two sectors in all the cities, the effect of vulnerability is nonlinear and convex since the coefficient of $I^{2}$ is positive and significant. This quadratic effect is significant at least at the 5\% level and mostly at the $1 \%$ level in all the cities and sectors, except in the formal private sector in Bamako. In formal Bamako businesses, vulnerability squared has no significant impact on earnings, just like firstdegree vulnerability.

So the convexity observed in the descriptive analysis holds in the formal and informal private sectors once the individual's characteristics, selection and endogeneity are controlled for. It can be seen in charts $2 \mathrm{a}$ and $2 \mathrm{~b}$, which represent the average income predicted by the Lee model with endogenisation of vulnerability by vulnerability level (the curves produced by the OLS model and the simple Lee model are similar).

In the formal private sector, income is convex in vulnerability intensity in all the capitals, albeit markedly decreasing. The curve is convex, but the slope does not change sign for low levels of vulnerability. A change of sign would only appear at vulnerability levels that are not well represented in terms of numbers (4 or more). In other words, income losses due to vulnerability are lower for high levels of vulnerability, but do not translate into gains. In Cotonou, however, the level of gains for a vulnerability of 4 is similar to the level of gains obtained for zero vulnerability.

In the informal sector, convexity is observed for all the cities. The earnings curves even steepen above a vulnerability level of 2 . In all the cities, average predicted income for a vulnerability of 4 or 5 is higher than the average predicted income for a vulnerability of 2 . In Cotonou, the average predicted income for a vulnerability of 5 is even higher than the average predicted income for workers who are not vulnerable at all.

The assumption that earnings can compensate for a certain level of vulnerability therefore holds in the informal sector. Workers with a vulnerability level of 2 endure this vulnerability, which is imposed on them by the labour market. The more vulnerable workers are better paid. In keeping with the theory of compensating wage differentials for dependent workers' jobs (see Section 2), this finding can be explained by the fact that their employers are encouraged to offer higher earnings to find employees prepared to work in such vulnerable jobs. For the independent workers, vulnerability can be a way of earning more immediate gains from their work. For example, an independent worker may choose not to have work premises, making her working 
conditions more vulnerable, if the itinerant nature of her work brings her into contact with her customers or means that she does not have to worry about paying rent or whatever taxes.

In the informal sector in all the cities, the marginal effect at average vulnerability is negative and slightly positive in Dakar. The average vulnerability points (approximately 2) are close to the minima of the convex curves. At these average points, income is a decreasing function of vulnerability. Yet above these points, earnings are an increasing function of vulnerability. A not-inconsiderable proportion of workers are found above the average vulnerability level. Therefore, the compensation or lesser-loss mechanism for high levels of vulnerability concerns a not-inconsiderable share of workers. Depending on the cities, from $27 \%$ to $62 \%$ of the workers in the formal private sector are more vulnerable than average (respectively in Abidjan and Cotonou) and from 38\% to $65 \%$ of informal sector workers are more vulnerable than average (respectively in Niamey and Lome).

In these cities, the labour market imposes an average level of vulnerability, as in the other cities. This imposed vulnerability is not compensated for since it is common to nearly all the workers: it is a characteristic of the job markets in these cities. It is not a wage bargaining element or a profit adjustment variable for the independent worker. However, workers can negotiate wage compensation for higher levels of vulnerability. If a dependent worker considers that she is more vulnerable than her fellow citizens on average, she is in a position to negotiate premium pay. If the market imposes a certain level of vulnerability on an independent worker, she will be inclined to make her job that bit more vulnerable to earn a higher income since, the way things stand, she "might as well".

\section{The endogeneity of vulnerability in the earnings function}

In all the cities' formal private sectors, the impact of vulnerability is all the more negative when the endogeneity of vulnerability is controlled for (Table 6). However, significance also drops. The underestimation of the negative impact of vulnerability implies that the workers have unobservable characteristics positively correlated with their earnings, but negatively correlated with the intensity of their vulnerability. More generally, unobservables affect the level of vulnerability and the level of earnings in opposite directions. These unobservables may reflect the dependent worker's bargaining capacities, but also her household's situation. For example, a dependent worker who has no bargaining power, who is shy or has no social network, is incapable of negotiating either good working conditions or a wage rise. Moreover, if the worker's household is insecure or if a shock should hit the household (illness, unemployment of another member, birth, etc.), the worker may have to hastily accept a low-paid vulnerable job if she does not have the time to negotiate better working conditions or financial compensation for the vulnerability. On the other hand, a worker with an extended social network and/or whose household is capable of coping with shocks would be in a better position to negotiate her working conditions and earnings. Social insecurity (poor network, tenuous household situation, etc.) may therefore be negatively correlated with the quality of working conditions and the level 
of earnings in the formal private sector. Conversely, an individual who has bargaining power due to an extended social network or who does not have to hastily find a job because he has other ways of responding to household shocks has the possibility of negotiating both his working conditions and his earnings.

In the informal sector, the negative impact of vulnerability disappears in the cities of Dakar and Cotonou when the endogeneity of vulnerability is corrected for: its coefficient is no longer significantly different from zero (Table 7). In the five other cities, vulnerability has a more pronounced negative impact on income once endogeneity is controlled for. Unobservable characteristics are again at work here in the opposite direction, affecting the intensity of vulnerability and the level of earnings. This sector is made up mainly of independent workers, for whom bargaining power is not so relevant. However, the interpretation in terms of social insecurity holds. An independent worker without an extended social network who is shaken by a household shock cannot make her business viable, stable or profitable (no time to invest, conduct market studies, etc.).

Lastly, the use of the control function provides a direct test of the assumption of the endogeneity of vulnerability in the earnings function. The significance of the coefficient assigned to the correction term $\hat{\mu}$ (the vulnerability equation residual) indicates whether the unexplained variation in vulnerability intensity also affects the variation in the level of individual earnings. In other words, in the cases where this coefficient is significant, the assumption of endogeneity of vulnerability cannot be rejected. The findings for the informal sector (Table 7) confirm that, in the majority of cases (four in seven), the endogeneity of vulnerability cannot be rejected. This contrasts with the diagnosis for the formal private sector (Table 6), where endogeneity has to be rejected in six of seven cases, the exception being Dakar. In the following, however, rather than using a method for each sector and each city, we refer to estimations derived from models corrected for endogeneity in all cases in order to maintain uniform treatment for all the cities studied. ${ }^{15}$

\subsection{Distributional approach}

This approach involves estimating model (5) for a certain number of income quantiles (see Section 4.2). For simplicity of presentation, we only report on the series of marginal effects of vulnerability calculated by deciles in charts $3 \mathrm{a}$ and $3 \mathrm{~b}$, respectively for the formal and informal private sectors. The curves presented are the third-degree trend curves, which are more flexible than the quadratic function. The marginal effects are calculated using the coefficients resulting from the quantile regressions, taking into account the endogeneity of vulnerability. In all the cities, the marginal effect of vulnerability on income, at the average vulnerability point, varies depending on its position in the earnings distribution.

\footnotetext{
${ }^{15}$ Using the control function solely for the cities in which endogeneity is observed does nothing to change the comparisons.
} 
In the formal private sector, the marginal effect of average vulnerability is negative across the entire distribution. This means that there is no compensating mechanism in the formal private sector at the average point. The cities of Niamey, Ouagadougou, Dakar, Cotonou and Lome present the same concave and then convex marginal effect curves; the points of inflection being close to median earnings in the distributions. The Malian capital's curve differs. It is solely concave and reaches its maximum for median earnings and a greater marginal effect than the other curves. However, one additional point of vulnerability prompts a $10 \%$ decrease in the earnings of an individual with average vulnerability in the fifth decile of the distribution. Abidjan's curve is slightly convex at the lower tail of the distribution and then concave. The marginal effect of vulnerability on earnings varies little along the distribution (from $20 \%$ to $30 \%$ income loss).

In the informal sector, Dakar, Cotonou and Bamako present a rising and mainly concave curve of the marginal effect of vulnerability along the conditional distribution of earnings. Moreover, the marginal effect becomes positive as of the third decile in Dakar and as of the sixth decile in Cotonou and Bamako. Hence for Dakar workers in the seventh decile with an average level of vulnerability, a one-point increase in vulnerability drives an average $25 \%$ increase in earnings. In Cotonou, a one-point increase in the vulnerability of workers in the ninth decile with average vulnerability generates an average increase of $15 \%$ to $20 \%$ in earnings. Lastly, Bamako returns a lower, but not negligible, effect since the increase in earnings can be as high as nearly $5 \%$ for workers in the eighth decile. In the other cities (Niamey, Ouagadougou, Lome and Abidjan), one additional degree of vulnerability produces no increase in earnings compared with average vulnerability, regardless of distribution position. In Niamey, however, the income losses caused by a one-point increase in vulnerability are smaller for the eighth and ninth deciles.

In Dakar, Cotonou and Bamako, the marginal effect of average vulnerability is positive for the higher deciles in the earnings distribution. Dakar, Cotonou and - to a lesser extent - Bamako display both the highest compensation for vulnerability, in terms of earnings for high levels of vulnerability, and positive effects of vulnerability on high earnings for average levels of vulnerability.

Hence in these three cities' informal sectors, vulnerability has a different effect on income depending on the worker's relative position on the remuneration scale. For equal observable characteristics, a worker at the lower tail of the earnings distribution (poor) is penalised in monetary terms for her vulnerability whereas a worker at the upper tail of the distribution (rich) is not and receives compensation for her vulnerability. This can be explained by greater bargaining power among the workers at the upper tail of the earnings distribution. The poorest independent workers cannot raise their income to compensate for the vulnerability of their work since, without room for manoeuvre, they cannot adopt a strategy to increase their profits. An independent worker at the upper tail of the earnings distribution could more easily make tradeoffs between working conditions and earnings. Furthermore, labour supply may well outstrip demand in low-income activity sectors. In this case, employers would not have to financially 
compensate for adverse working conditions while own-account workers would not be able to afford to raise their mark-up.

\subsection{Qualitative approach}

The approach taken up to this point cannot distinguish between the different roles of each aspect of vulnerability. There is a possibility that only certain facets of vulnerability are behind the compensating phenomena found above. The analysis therefore focuses on the different vulnerability criteria. Since these criteria are sometimes collinear, it is better to conduct a factor analysis in order to build orthogonal axes.

\section{Results of the principal component analysis}

The first PCA factor axis for dependent workers is defined mainly by the informal nature of the contract, casual labour and unstable remuneration, and adverse working conditions (Table 8 ). This axis hence covers three aspects of vulnerability: contractual insecurity, adverse working conditions and the casual nature of employment. The second axis defines subsistence and stopgap jobs. Having lost her previous job, the worker finds herself on a downward professional slope and accepts the first job she finds, which is far from being the job she wants. This job may therefore be mismatched with her skills. The third axis for dependent workers is underemployment since the variables that contribute the most to it are visible underemployment and casual labour. Underemployment is associated with piece-rate work and day work, since a casual worker finds it hard to work full time and is therefore subject to low demand. The fourth axis is working a second highly vulnerable job. Working a second highly vulnerable job is a reflection of vulnerability in the main job, as distinct from the vulnerability induced by underemployment, since the third and fourth axes are orthogonal.

The first PCA axis for independent workers corresponds to the second axis for dependent workers, the subsistence job axis. The second axis covers underemployment. Unlike the underemployment axis for dependent workers, here the unstable remuneration variable contributes to the axis. If an independent worker's work is not steady, then her remuneration is automatically variable since own-account workers and self-employed employers find it hard to smooth their income. The third axis for independent workers covers having no employees, a variable defined solely for these workers, and adverse working conditions. This axis characterises itinerant jobs low on physical capital (low on physical capital since there are no work premises and low labour factor since worked by just one person), such as repairers and roving street vendors. The fourth axis is the same as the fourth axis for dependent workers: working a second highly vulnerable job.

\section{Earnings equations with the factor axes}

The results of the two tested specifications (segmentation of the informal sector sample and interactions, see Section 4.3) are virtually identical. Therefore, we only present the results of crossing the factor axis with independent or dependent status (Tables 9 and 10). In addition, 
since the OLS and Lee models produce similar results, we only report on the Lee model results here.

The independent workers' axes very rarely play a significant role in the formal private sector due to the small proportion of independent workers in this sector. We therefore do not comment on these coefficients.

The contractual insecurity and adverse working conditions axis has a definitely negative and highly significant impact (at 1\%) on the earnings of dependent workers in the formal private sector in all the economic capitals. The impact of dependent workers employed in a subsistence job, taken on as a last resort, is significantly negative in Niamey (at 5\%), Bamako (at 5\%) and Abidjan (at 5\%). In the other cities, its impact is not significantly different from zero. The underemployment axis has a positive and highly significant effect on earnings in the formal private sector in all the cities except Dakar, where the effect is not significant. Lastly, working a second job has no impact on the income earned in the main job.

The contractual insecurity axis has a negative and significant impact (except in Bamako) on the earnings of dependent workers in the informal sector. The underemployment axis positively and significantly affects the earnings of dependent workers in the informal sector in all the cities. For these workers, the subsistence job axis coefficient is never significantly different to zero and the coefficient for working a second vulnerable job is only significantly negative in Cotonou.

The subsistence job axis has no clear effect on the earnings of independent workers in the informal sector. However, underemployment here again has a significantly positive impact on the earnings of independent workers in the informal sectors of the seven cities, while the axis defined by zero employees and adverse working conditions has a significantly negative impact at the $1 \%$ level in all the cities except Dakar. Working a second job has a significantly negative impact on earnings, except in Ouagadougou.

Different aspects of vulnerability therefore have different impacts on earnings. For example, subsistence jobs tend to have a negative effect, although it is rarely significant. Working a second job has a negative effect on the earnings of independent workers in the informal sector, but no impact in the formal private sector. So working a second vulnerable job would be a sign of main job vulnerability in the informal sector, a way of diversifying excessive risks. However, for a worker in the formal private sector, working a second vulnerable job is not a sign of lower earnings in the main job, but a "sideline" to prepare for formal retirement, just like public sector workers. Lastly, there is no compensation for contractual insecurity among dependent workers or for itinerant, solitary work among independent workers in any of the cities or the institutional sectors.

Visible underemployment has a positive impact on the earnings of dependent workers in both sectors and independent workers in the informal sector. Here, then, a pecuniary compensating mechanism for vulnerability is at work. An employer cannot pay his employee exactly pro rata to the hours worked if the number of hours worked is constrained by customer 
demand and not by the employee's wishes. The employee will negotiate to bring her earnings up to the minimum living wage, even if this is supposed to be earned from a greater number of hours than those actually worked. So pecuniary compensation for vulnerability would depend on the worker's bargaining power to secure daily, weekly or monthly earnings that will enable her household to survive, earnings virtually equal to those of an employee working longer hours. For independent workers, a possible explanation for this compensation is that the independent worker will bill her services in a way that will give her a certain level of earnings, regardless of the number of hours worked. Lastly, underemployed workers may have made less of an effort to work more than the individuals who work longer than the statutory working week, simply because their hourly wage is higher.

\section{Conclusion}

In this paper, we develop indicators of employment vulnerability in seven West African economic capitals (Abidjan, Bamako, Cotonou, Dakar, Lome, Niamey and Ouagadougou) and study their links with individual earnings from the main job. The theory of compensating differentials, formalised in the 1980s, states that workers may receive pecuniary compensation commensurate with the strenuous or hazardous nature of their tasks or adverse working conditions. A certain number of empirical studies have recently found evidence of this type of compensation in developed countries, but often with contradictory conclusions. Our interpretation of the link between employment status and income draws on these developments, applying them not just to working conditions themselves, but more broadly to vulnerability in employment (contractual insecurity, working conditions, underemployment, and stopgap jobs mismatched with individual characteristics). This is a dominant characteristic of the urban labour markets in sub-Saharan Africa, where the overwhelming majority of workers work in insecure jobs and/or in the informal sector.

Our analysis of the effects of vulnerability on earnings is in turn quantitative, distributional and qualitative. The first analysis sets out to answer the question of whether vulnerability has different effects on income depending on its intensity. The second analysis studies differences between any compensating phenomena along the individual earnings distribution. The qualitative analysis differentiates between the different facets of vulnerability and looks at which aspects might be compensated.

Our composite indicator of vulnerability in employment reveals that $17 \%$ of the dependent workers in the private sector and $14 \%$ of the independent workers in the private sector are not at all vulnerable since they fulfil none of our vulnerability criteria. Nevertheless, these percentages mask huge differences between the formal and informal private sectors. In the informal sector alone, these rates fall to $2 \%$ and $12 \%$ respectively. This means that $85 \%$ of the private sector 
workers in all the economic capitals studied are vulnerable on the basis of at least one criterion. This would suggest that all the cities' labour markets impose a minimum level of vulnerability.

The quantitative analysis finds that the impact of vulnerability on earnings is negative for an average level of vulnerability (or slightly positive in Dakar). In the formal private sector, income losses due to vulnerability are lower for high levels of vulnerability, but do not translate into gains. In Cotonou, for example, the level of earnings for average vulnerability on our intensity scale is close to the level of earnings obtained for zero vulnerability. In the informal sector, however, the average predicted income for high vulnerability is higher than the average predicted income for relatively low vulnerability. In the case of Cotonou, the average predicted income for level 5 vulnerability (on a scale of 8 ) is even higher than the average predicted income for workers who are not vulnerable. The assumption that average earnings may compensate for a certain level of vulnerability is thus confirmed in the informal sector. This could partly explain why the informal sector is attracting more workers than the formal sector. This compensation or lesser-loss mechanism for high levels of vulnerability is moreover found to concern a notinconsiderable share of workers. However, imposed "minimum" vulnerability is not compensated for since it is common to nearly all workers: it is an inherent characteristic of the job markets in these cities.

The abovementioned marginal effect is estimated by regressions on the earnings average, which conceals variations in the magnitude of the impact of vulnerability along the earnings distribution. Our quantile regressions find evidence that the impact of vulnerability on earnings is not uniform, particularly in the informal sector. For example, in the informal sectors in Dakar, Cotonou and Bamako, the marginal effect of average vulnerability is positive for the upper deciles of the earnings distribution. These cities - Dakar, Cotonou and, to a lesser extent, Bamako - display both the highest compensation for high levels of vulnerability and positive effects of average vulnerability on income among the highest earnings.

For example, for average levels of vulnerability, compensating wage differentials are found for earnings at the upper tail of the distribution. However, the compensating mechanism does not concern the poorest workers. Although the poorest dependent workers should be the most forceful in wage bargaining in an endeavour to earn a living wage, they have less bargaining power due to the urgent nature of their needs. Urban labour market imbalances could also explain this absence of compensating wage differentials at the lower tail of the distribution, there where labour supply probably far exceeds demand. ${ }^{16}$ Similarly, the poorest independent workers suffer more from their vulnerability and do not adopt strategies to compensate for it by increasing their profits (raising receipts or reducing expenditure). An independent worker at the

\footnotetext{
${ }^{16}$ For example, Fernandez and Nordman (2009) interpret the absence of compensating wage differentials for working conditions at the tail ends of the earnings distribution in the United Kingdom as evidence of a "missing middle » in the distribution of manpower skills in this country. In other words, where labour demand exceeds labour supply, employers would be more inclined to compensate for adverse working conditions.
} 
upper tail of the earnings distribution could more easily make trade-offs between working conditions and earnings.

However, the different aspects of vulnerability have diverse impacts on income. For example, working a second vulnerable job has a negative effect on the average earnings of independent workers in the informal sector, but no impact in the formal private sector. So working a second insecure job could be seen as a sign of a vulnerable main job in the informal sector, a way of diversifying excessive risks. Although there is no compensation for contractual insecurity among dependent workers or for itinerant, solitary work among independent workers in any of the cities or institutional sectors, visible underemployment has a positive impact on the average earnings of dependent workers in both sectors and independent workers in the informal sector. Here, then, a pecuniary compensating mechanism for vulnerability is definitely at work.

In a nutshell, vulnerability compensating mechanism is mainly seen in the informal sector, in the upper tail of the earning distribution, and particularly in the circumstance of visible underemployment. This means that vulnerability, which is the norm in West African cities, is not compensated for the largest part of the labour force, i.e. the full-time workers in the private sector. The private formal sector does not offer the best protection against the common features of employment vulnerability. 


\section{Appendices}

Table 1: Samples used

\begin{tabular}{|c|c|c|c|c|c|c|c|c|}
\hline & & Niamey & Ouagadougou & Dakar & Bamako & Cotonou & Lome & Abidjan \\
\hline \multicolumn{2}{|l|}{ Sample total } & 14,524 & 13,733 & 19,054 & 13,002 & 11,574 & 9,906 & 11,343 \\
\hline \multicolumn{2}{|c|}{ Working-age population (WAP) } & 8,284 & 8,525 & 12,487 & 7,529 & 7,639 & 6,418 & 7,503 \\
\hline \multicolumn{2}{|c|}{ WAP with five or more years of potential experience } & 7,269 & 7,328 & 11,014 & 6,561 & 6,517 & 6,546 & 6,537 \\
\hline \multirow{8}{*}{$\begin{array}{l}\text { Regression } \\
\text { samples }\end{array}$} & Zero income & 4,053 & 3,663 & 6,074 & 2,746 & 2,374 & 2,081 & 2,568 \\
\hline & Public sector (positive income) & 577 & 584 & 498 & 457 & 398 & 306 & 302 \\
\hline & Formal private sector (positive income): & 409 & 336 & 950 & 452 & 509 & 302 & 825 \\
\hline & - Dependent & 373 & 307 & 868 & 365 & 423 & 261 & 782 \\
\hline & - Independent & 36 & 29 & 82 & 87 & 86 & 41 & 43 \\
\hline & Informal private sector (positive income): & 2,230 & 2,745 & 3,492 & 2,906 & 3,236 & 2,857 & 2,842 \\
\hline & - Dependent & 562 & 724 & 1,123 & 528 & 460 & 508 & 894 \\
\hline & - Independent & 1,668 & 2,021 & 2,369 & 2,378 & 2,776 & 2,349 & 1,948 \\
\hline
\end{tabular}

Source: 1-2-3 Surveys, authors' calculations. 
Table 2: Distribution of vulnerability criteria in all seven cities

\begin{tabular}{|c|c|c|c|c|}
\hline & & $\begin{array}{l}\text { Formal } \\
\text { private }\end{array}$ & $\begin{array}{l}\text { Informal } \\
\text { private }\end{array}$ & $\begin{array}{l}\text { Total private } \\
\text { sector }\end{array}$ \\
\hline \multirow{3}{*}{$\begin{array}{l}\text { Contractual insecurity: } \\
\text { no contract OR no payslip }\end{array}$} & Independent & & & \\
\hline & Dependent & 0.49 & 0.97 & 0.76 \\
\hline & All & & & \\
\hline \multirow{3}{*}{$\begin{array}{l}\text { Independent with no employees } \\
\text { (wage-earning or otherwise) }\end{array}$} & Independent & 0.11 & 0.68 & 0.66 \\
\hline & Dependent & & & \\
\hline & All & & & \\
\hline \multirow{3}{*}{$\begin{array}{l}\text { Adverse working conditions: } \\
\text { premises not dedicated to the job }\end{array}$} & Independent & 0.17 & 0.60 & 0.59 \\
\hline & Dependent & 0.05 & 0.22 & 0.15 \\
\hline & All & 0.06 & 0.50 & 0.42 \\
\hline \multirow{3}{*}{$\begin{array}{l}\text { Casual labour: } \\
\text { Piece-rate, day or seasonal work }\end{array}$} & Independent & 0.13 & 0.20 & 0.20 \\
\hline & Dependent & 0.10 & 0.15 & 0.13 \\
\hline & All & 0.10 & 0.19 & 0.17 \\
\hline \multirow{3}{*}{$\begin{array}{l}\text { Unstable remuneration: paid in a form other than } \\
\text { a fixed wage (monthly, fortnightly or weekly) or, for } \\
\text { independent workers, in a form other than profits }\end{array}$} & Independent & 0.06 & 0.05 & 0.05 \\
\hline & Dependent & 0.18 & 0.40 & 0.31 \\
\hline & All & 0.17 & 0.14 & 0.15 \\
\hline \multirow{3}{*}{$\begin{array}{l}\text { Visible underemployment: } \\
\text { Works fewer hours than the statutory working week } \\
\text { AND would like to work more }\end{array}$} & Independent & 0.09 & 0.13 & 0.13 \\
\hline & Dependent & 0.07 & 0.07 & 0.07 \\
\hline & All & 0.07 & 0.12 & 0.11 \\
\hline \multirow{3}{*}{$\begin{array}{l}\text { Working a second vulnerable job: outside the } \\
\text { public sector in a place or premises not dedicated to } \\
\text { the job and in a firm of less than } 5 \text { people }\end{array}$} & Independent & 0.00 & 0.02 & 0.02 \\
\hline & Dependent & 0.01 & 0.01 & 0.01 \\
\hline & All & 0.01 & 0.01 & 0.01 \\
\hline \multirow{3}{*}{$\begin{array}{l}\text { Employment instability: } \\
\text { on a downwardly mobile or unstable career path }\end{array}$} & Independent & 0.01 & 0.03 & 0.03 \\
\hline & Dependent & 0.08 & 0.08 & 0.08 \\
\hline & All & 0.07 & 0.04 & 0.05 \\
\hline \multirow{3}{*}{$\begin{array}{l}\text { unwanted job: involuntary departure from the } \\
\text { previous job or job dissatisfaction }\end{array}$} & Independent & 0.05 & 0.06 & 0.06 \\
\hline & Dependent & 0.09 & 0.06 & 0.07 \\
\hline & All & 0.09 & 0.06 & 0.06 \\
\hline \multirow{3}{*}{$\begin{array}{l}\text { vulnerable: meets at least one of the vulnerability } \\
\text { criteria }\end{array}$} & Independent & 0.42 & 0.87 & 0.86 \\
\hline & Dependent & 0.62 & 0.98 & 0.82 \\
\hline & All & 0.60 & 0.90 & 0.85 \\
\hline
\end{tabular}

Source: 1-2-3 Surveys, authors' calculations on the weighted data.

Interpretation: The mean of the contractual insecurity variable for the subsample of formal private sector dependent workers who report strictly positive earnings is 0.49 . This means that $49 \%$ of the dependent workers in the formal private sector do not have a written contract or do not receive a payslip. 
Table 3: Distribution of vulnerability intensity

\begin{tabular}{|c|c|c|c|c|c|c|c|c|c|c|c|c|c|c|}
\hline & \multicolumn{2}{|c|}{ Niamey } & \multicolumn{2}{|c|}{ Ouagadougou } & \multicolumn{2}{|c|}{ Dakar } & \multicolumn{2}{|c|}{ Bamako } & \multicolumn{2}{|c|}{ Cotonou } & \multicolumn{2}{|c|}{ Lome } & \multicolumn{2}{|c|}{ Abidjan } \\
\hline \multicolumn{15}{|c|}{ Distribution of vulnerability intensity in the formal private sector } \\
\hline $\begin{array}{c}\text { Intensity } \\
(0 \text { to } 8)\end{array}$ & Numbers & $\begin{array}{c}\text { Cumulative } \\
\%\end{array}$ & Numbers & $\begin{array}{c}\text { Cumulative } \\
\%\end{array}$ & Numbers & $\begin{array}{c}\text { Cumulative } \\
\%\end{array}$ & Numbers & $\begin{array}{c}\text { Cumulative } \\
\%\end{array}$ & Numbers & $\begin{array}{c}\text { Cumulative } \\
\% \\
\end{array}$ & Numbers & $\begin{array}{c}\text { Cumulative } \\
\%\end{array}$ & Numbers & $\begin{array}{c}\text { Cumulative } \\
\%\end{array}$ \\
\hline 0 & 136 & $(33.25)$ & 129 & $(38.39)$ & 424 & $(44.63)$ & 185 & $(40.93)$ & 194 & $(38.11)$ & 90 & $(29.80)$ & 321 & $(38.91)$ \\
\hline 1 & 112 & $(27.38)$ & 110 & (32.74) & 243 & $(25.58)$ & 175 & $(38.72)$ & 199 & $(39.10)$ & 116 & (38.41) & 280 & (33.94) \\
\hline 2 & 87 & $(21.27)$ & 55 & $(16.37)$ & 160 & (16.84) & 68 & $(15.04)$ & 69 & $(13.56)$ & 58 & (19.21) & 145 & $(17.58)$ \\
\hline 3 & 46 & $(11.25)$ & 26 & (07.74) & 88 & $(09.26)$ & 19 & $(04.20)$ & 35 & (06.88) & 27 & (08.94) & 42 & $(05.09)$ \\
\hline 4 & 23 & $(05.62)$ & 16 & $(04.76)$ & 29 & (03.05) & 5 & (01.11) & 11 & $(02.16)$ & 7 & $(02.32)$ & 28 & $(03.39)$ \\
\hline 5 & 4 & (00.98) & 0 & $(00.00)$ & 6 & $(00.63)$ & 0 & $(00.00)$ & 0 & $(00.00)$ & 3 & (00.99) & 8 & $(00.97)$ \\
\hline 6 & 1 & $(00.24)$ & 0 & $(00.00)$ & 0 & $(00.00)$ & 0 & $(00.00)$ & 1 & $(00.20)$ & 1 & $(00.33)$ & 1 & $(00.12)$ \\
\hline 7 & 0 & $(00.00)$ & 0 & $(00.00)$ & 0 & $(00.00)$ & 0 & $(00.00)$ & 0 & $(00.00)$ & 0 & $(00.00)$ & 0 & $(00.00)$ \\
\hline Total & 409 & (100.00) & 336 & (100.00) & 950 & (100.00) & 452 & $(100.00)$ & 509 & $(100.00)$ & 302 & $(100.00)$ & 825 & (100.00) \\
\hline
\end{tabular}

\begin{tabular}{|c|c|c|c|c|c|c|c|c|c|c|c|c|c|c|}
\hline 0 & 126 & $(05.65)$ & 329 & (11.99) & 286 & (08.19) & 263 & (09.05) & 306 & (09.46) & 267 & (09.35) & 347 & (12.21) \\
\hline 1 & 502 & $(22.51)$ & 848 & $(30.89)$ & 1,077 & $(30.84)$ & 933 & (32.11) & 1,029 & $(31.80)$ & 738 & $(25.83)$ & 995 & (35.01) \\
\hline 2 & 761 & $(34.13)$ & 907 & $(33.04)$ & 1,102 & $(31.56)$ & 1,035 & $(35.62)$ & 1,241 & $(38.35)$ & 1,052 & $(36.82)$ & 972 & $(34.20)$ \\
\hline 3 & 502 & $(22.51)$ & 450 & $(16.39)$ & 644 & (18.44) & 495 & $(17.03)$ & 488 & (15.08) & 508 & $(17.78)$ & 372 & (13.09) \\
\hline 4 & 263 & $(11.79)$ & 166 & $(06.05)$ & 300 & $(08.59)$ & 154 & $(05.30)$ & 151 & $(04.67)$ & 235 & $(08.23)$ & 124 & $(04.36)$ \\
\hline 5 & 68 & (03.05) & 40 & (01.46) & 72 & $(02.06)$ & 25 & $(00.86)$ & 19 & $(00.59)$ & 49 & $(01.72)$ & 23 & $(00.81)$ \\
\hline 6 & 8 & $(00.36)$ & 5 & $(00.18)$ & 10 & $(00.29)$ & 1 & $(00.03)$ & 2 & $(00.06)$ & 8 & $(00.28)$ & 8 & $(00.28)$ \\
\hline 7 & 0 & $(00.00)$ & 0 & $(00.00)$ & 1 & $(00.03)$ & 0 & $(00.00)$ & 0 & $(00.00)$ & 0 & $(00.00)$ & 1 & $(00.04)$ \\
\hline Total & 2,230 & $(100.00)$ & 2,745 & $(100.00)$ & 3,492 & $(100.00)$ & 2,906 & $(100.00)$ & 3,236 & $(100.00)$ & 2,857 & (100.00) & 2,842 & (100.00) \\
\hline
\end{tabular}

Interpretation: The lines cutting across the distributions represent the average vulnerability intensity position. For example, in the formal private sector in Niamey, average vulnerability is 1.3 so a line is drawn between 1 and 2 . 
Chart 1a: Average income by vulnerability intensity

(Formal private sector)

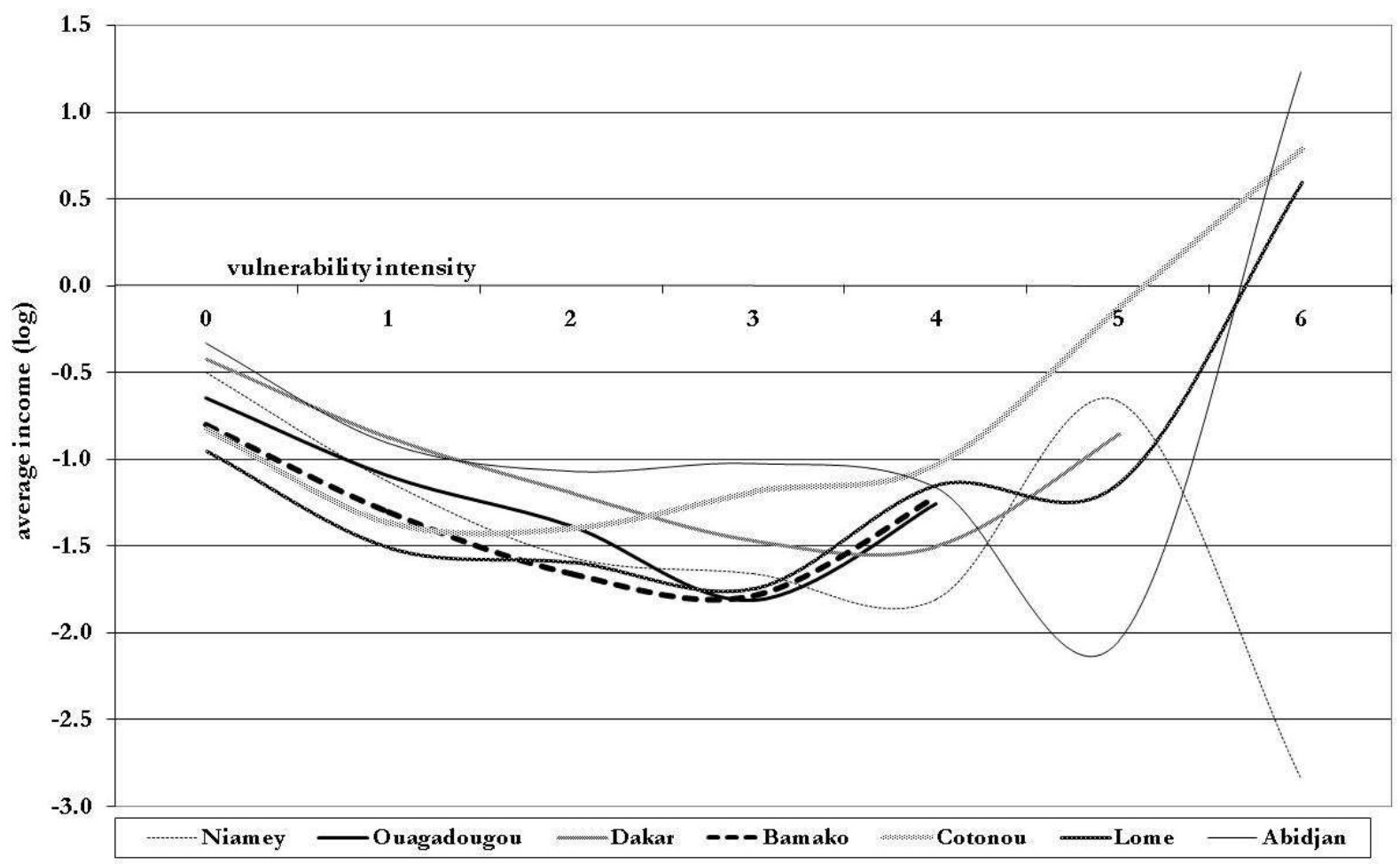

Chart 1b: Average income by vulnerability intensity

(Informal sector)

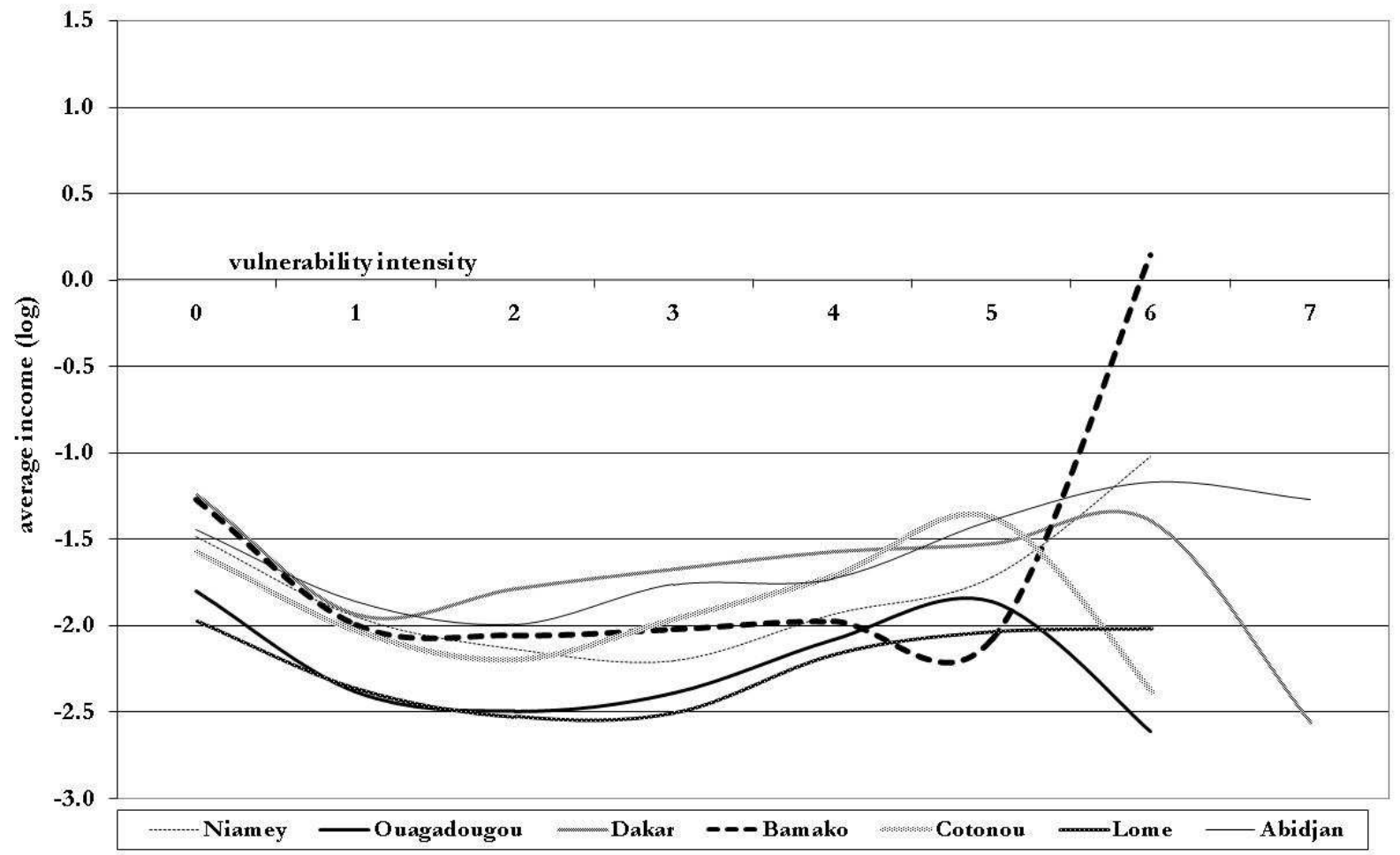


Table 4: Quality of vulnerability endogeneity control function instruments

(Vulnerability intensity determinants in ordinary least squares)

\begin{tabular}{|c|c|c|c|c|c|c|c|c|c|c|c|c|c|c|}
\hline & \multicolumn{7}{|c|}{ Formal private sector } & \multicolumn{7}{|c|}{ Informal private sector } \\
\hline & Niamey & $\begin{array}{l}\text { Ouaga- } \\
\text { dougou }\end{array}$ & Dakar & Bamako & Cotonou & Lome & Abidjan & Niamey & $\begin{array}{l}\text { Ouaga- } \\
\text { dougou }\end{array}$ & Dakar & Bamako & Cotonou & Lome & Abidjan \\
\hline $\begin{array}{l}\text { Household } \\
\text { head }\end{array}$ & $\begin{array}{l}-0.111 \\
(0.178)\end{array}$ & $\begin{array}{c}-0.249 * \\
(0.149)\end{array}$ & $\begin{array}{l}-0.221 * * \\
(0.096)\end{array}$ & $\begin{array}{l}-0.268 \\
(0.174)\end{array}$ & $\begin{array}{c}0.208^{*} \\
(0.116)\end{array}$ & $\begin{array}{l}0.066 \\
(0.175)\end{array}$ & $\begin{array}{l}-0.196^{* *} \\
(0.094)\end{array}$ & $\begin{array}{l}-0.164^{* *} \\
(0.067)\end{array}$ & $\begin{array}{l}-0.263^{* * *} \\
(0.059)\end{array}$ & $\begin{array}{l}-0.055 \\
(0.062)\end{array}$ & $\begin{array}{l}-0.231 \text { *** } \\
(0.064)\end{array}$ & $\begin{array}{l}-0.040 \\
(0.044)\end{array}$ & $\begin{array}{l}-0.144 * * * \\
(0.050)\end{array}$ & $\begin{array}{l}-0.213^{* * *} \\
(0.057)\end{array}$ \\
\hline
\end{tabular}

Father's institutional sector (reference: public sector)

\begin{tabular}{|c|c|c|c|c|c|c|c|c|c|c|c|c|c|c|}
\hline $\begin{array}{l}\text { Formal } \\
\text { private }\end{array}$ & $\begin{array}{l}-0.224 \\
(0.210)\end{array}$ & $\begin{array}{l}0.151 \\
(0.268)\end{array}$ & $\begin{array}{l}-0.240^{* *} \\
(0.099)\end{array}$ & $\begin{array}{l}0.163 \\
(0.181)\end{array}$ & $\begin{array}{c}0.080 \\
(0.147)\end{array}$ & $\begin{array}{c}-0.384 * \\
(0.203)\end{array}$ & $\begin{array}{l}0.094 \\
(0.128)\end{array}$ & $\begin{array}{l}0.441^{* * *} \\
(0.155)\end{array}$ & $\begin{array}{c}-0.187 * \\
(0.104)\end{array}$ & $\begin{array}{c}-0.155^{* *} \\
(0.079)\end{array}$ & $\begin{array}{l}-0.128 \\
(0.100)\end{array}$ & $\begin{array}{l}-0.065 \\
(0.077)\end{array}$ & $\begin{array}{l}-0.082 \\
(0.090)\end{array}$ & $\begin{array}{l}0.126 \\
(0.091)\end{array}$ \\
\hline $\begin{array}{l}\text { Informal } \\
\text { private }\end{array}$ & $\begin{array}{l}-0.059 \\
(0.178)\end{array}$ & $\begin{array}{c}0.093 \\
(0.156)\end{array}$ & $\begin{array}{l}-0.014 \\
(0.112)\end{array}$ & $\begin{array}{c}0.069 \\
(0.107)\end{array}$ & $\begin{array}{c}0.177 \\
(0.117)\end{array}$ & $\begin{array}{c}0.046 \\
(0.170)\end{array}$ & $\begin{array}{c}0.036 \\
(0.104)\end{array}$ & $\begin{array}{c}0.084 \\
(0.095)\end{array}$ & $\begin{array}{l}-0.231 * * * \\
(0.077)\end{array}$ & $\begin{array}{c}-0.144 * * \\
(0.069)\end{array}$ & $\begin{array}{l}-0.126 * \\
(0.065)\end{array}$ & $\begin{array}{c}-0.104 * \\
(0.056)\end{array}$ & $\begin{array}{l}-0.077 \\
(0.059)\end{array}$ & $\begin{array}{l}-0.010 \\
(0.074)\end{array}$ \\
\hline Unknown & $\begin{array}{l}-0.017 \\
(0.179)\end{array}$ & $\begin{array}{l}0.069 \\
(0.156)\end{array}$ & $\begin{array}{c}0.022 \\
(0.097)\end{array}$ & $\begin{array}{l}0.019 \\
(0.128)\end{array}$ & $\begin{array}{l}0.185 \\
(0.118)\end{array}$ & $\begin{array}{c}0.176 \\
(0.243)\end{array}$ & $\begin{array}{c}0.082 \\
(0.141)\end{array}$ & $\begin{array}{l}-0.019 \\
(0.098)\end{array}$ & $\begin{array}{l}-0.356^{* * *} \\
(0.086)\end{array}$ & $\begin{array}{l}-0.199 * * * \\
(0.071)\end{array}$ & $\begin{array}{c}-0.154^{* *} \\
(0.069)\end{array}$ & $\begin{array}{c}-0.112^{*} \\
(0.059)\end{array}$ & $\begin{array}{l}-0.080 \\
(0.066)\end{array}$ & $\begin{array}{l}-0.012 \\
(0.082)\end{array}$ \\
\hline Observations & 409 & 336 & 950 & 452 & 509 & 302 & 825 & 2,230 & 2,745 & 3,492 & 2,906 & 3,236 & 2,857 & 2,842 \\
\hline Adjusted $\mathrm{R}^{2}$ & 0.16 & 0.24 & 0.18 & 0.12 & 0.12 & 0.14 & 0.14 & 0.04 & 0.07 & 0.02 & 0.08 & 0.05 & 0.05 & 0.06 \\
\hline
\end{tabular}

Source: 1-2-3 Surveys, authors' calculations

Notes: The standard deviations are bootstrapped (500 replications). Significance of the coefficients: *: at the $10 \%$ level; ** at the $5 \%$ level; *** at the $1 \%$ level.

The other variables introduced into the model are a dummy variable for gender, an education variable (number of years of successfully completed education), potential experience and seniority in the firm, religion (Christian, reference: Muslim), migratory status (rural, urban or foreign migrant, reference: native of the city studied), marital status (conjugal status, reference: widowed, divorced or single), and independent status (self-employed employer or own-account worker versus dependent worker). 
Table 5: Marginal effects of vulnerability intensity on earnings

\begin{tabular}{|c|c|c|c|c|c|c|c|}
\hline & Niamey & Ouagadougou & Dakar & Bamako & Cotonou & Lome & Abidjan \\
\hline \multicolumn{8}{|c|}{ Marginal effect at the average vulnerability point in the formal private sector } \\
\hline No selection correction, exogenous vulnerability & $-14.3 \%$ & $-9.3 \%$ & $-16.2 \%$ & $-13.9 \%$ & $-10.9 \%$ & $-7.4 \%$ & $-12.6 \%$ \\
\hline Selection correction, exogenous vulnerability & $-14.2 \%$ & $-9.3 \%$ & $-16.2 \%$ & $-13.8 \%$ & $-10.9 \%$ & $-7.0 \%$ & $-12.5 \%$ \\
\hline Selection correction, endogenous vulnerability & $-23.0 \%$ & $-22.5 \%$ & $-33.5 \%$ & $-37.3 \%$ & $-15.5 \%$ & $-24.8 \%$ & $-24.2 \%$ \\
\hline Observations & 409 & 336 & 950 & 452 & 509 & 302 & 825 \\
\hline Average intensity & 1.325 & 1.077 & 1.024 & 0.858 & 0.967 & 1.199 & 1.035 \\
\hline \multicolumn{8}{|c|}{ Marginal effect at the average vulnerability point in the informal sector } \\
\hline No selection correction, exogenous vulnerability & $-1.0 \%$ & $-1.7 \%$ & $0.2 \%$ & $-1.3 \%$ & $-0.6 \%$ & $-0.1 \%$ & $-2.8 \%$ \\
\hline Selection correction, exogenous vulnerability & $-1.0 \%$ & $-1.6 \%$ & $0.2 \%$ & $-1.3 \%$ & $-0.7 \%$ & $-0.3 \%$ & $-2.9 \%$ \\
\hline Selection correction, endogenous vulnerability & $-9.7 \%$ & $-15.6 \%$ & $1.0 \%$ & $-17.2 \%$ & $-3.4 \%$ & $-13.1 \%$ & $-19.9 \%$ \\
\hline Observations & 2,230 & 2,745 & 3,492 & 2,906 & 3,236 & 2,857 & 2,842 \\
\hline Average intensity & 2.229 & 1.787 & 1.959 & 1.801 & 1.757 & 1.960 & 1.661 \\
\hline
\end{tabular}

Source: 1-2-3 Surveys, authors' calculations.

Note: Calculation of the marginal effect at the average point of intensity (denoted $\overline{\mathrm{I}}): \log (\mathrm{y})=\mathrm{a} \cdot \mathrm{I}+\mathrm{b} \cdot \mathrm{I}^{2} \Rightarrow \mathrm{y}=\exp \left(\mathrm{a} \cdot \mathrm{I}+\mathrm{b} \cdot \mathrm{I}^{2}\right) \Rightarrow \operatorname{em}(\overline{\mathrm{I}})=\frac{\partial \mathrm{y}}{\partial \mathrm{I}}(\overline{\mathrm{I}})=(\hat{\mathrm{a}}+2 \hat{\mathrm{b}} \overline{\mathrm{I}}) \cdot \exp \left(\hat{\mathrm{a}} \cdot \overline{\mathrm{I}}+\hat{\mathrm{b}} \cdot \overline{\mathrm{I}}^{2}\right)$ 
Table 6: Effect of vulnerability on earnings in the formal private sector

\begin{tabular}{|c|c|c|c|c|c|c|c|}
\hline & \multicolumn{7}{|c|}{ Formal private sector } \\
\hline & Niamey & Ouagadougou & Dakar & Bamako & Cotonou & Lome & Abidjan \\
\hline \multicolumn{8}{|l|}{ OLS } \\
\hline$I$ & $\begin{array}{l}-0.418^{* * *} \\
(0.090)\end{array}$ & $\begin{array}{l}-0.418^{* * *} \\
(0.095)\end{array}$ & $\begin{array}{l}-0.247 * * * \\
(0.096)\end{array}$ & $\begin{array}{l}-0.304^{* * *} \\
(0.058)\end{array}$ & $\begin{array}{l}-0.223^{* *} \\
(0.104)\end{array}$ & $\begin{array}{l}-0.285^{* * *} \\
(0.076)\end{array}$ & $\begin{array}{l}-0.304 * * * \\
(0.116)\end{array}$ \\
\hline$I^{2}$ & $\begin{array}{l}0.076^{* * *} \\
(0.025)\end{array}$ & $\begin{array}{l}0.076^{* * *} \\
(0.025)\end{array}$ & $\begin{array}{l}0.062^{* *} \\
(0.027)\end{array}$ & $\begin{array}{l}0.046^{* * *} \\
(0.016)\end{array}$ & $\begin{array}{c}0.034 \\
(0.033)\end{array}$ & $\begin{array}{l}0.079 * * * \\
(0.023)\end{array}$ & $\begin{array}{l}0.088^{* * *} \\
(0.032)\end{array}$ \\
\hline Adjusted $\mathrm{R}^{2}$ & 0.52 & 0.52 & 0.53 & 0.41 & 0.39 & 0.40 & 0.41 \\
\hline Obs. & 409 & 336 & 950 & 452 & 509 & 302 & 825 \\
\hline \multicolumn{8}{|l|}{ Lee model } \\
\hline$I$ & $\begin{array}{l}-0.414 * * * \\
(0.092)\end{array}$ & $\begin{array}{l}-0.252^{* * *} \\
(0.096)\end{array}$ & $\begin{array}{l}-0.304^{* * *} \\
(0.062)\end{array}$ & $\begin{array}{l}-0.219^{* *} \\
(0.103)\end{array}$ & $\begin{array}{l}-0.286^{* * *} \\
(0.079)\end{array}$ & $\begin{array}{l}-0.297 * * \\
(0.129)\end{array}$ & $\begin{array}{l}-0.220^{* * *} \\
(0.058)\end{array}$ \\
\hline$I^{2}$ & $\begin{array}{l}0.075^{* * *} \\
(0.025)\end{array}$ & $\begin{array}{l}0.064^{* *} \\
(0.028)\end{array}$ & $\begin{array}{l}0.046^{* * *} \\
(0.017)\end{array}$ & $\begin{array}{l}0.033 \\
(0.034)\end{array}$ & $\begin{array}{l}0.079 * * * \\
(0.025)\end{array}$ & $\begin{array}{l}0.087 * * \\
(0.037)\end{array}$ & $\begin{array}{l}0.033^{* *} \\
(0.016)\end{array}$ \\
\hline$\lambda_{h}$ & $\begin{array}{l}-0.460^{* *} \\
(0.199)\end{array}$ & $\begin{array}{l}0.225 \\
(0.238) \\
\end{array}$ & $\begin{array}{c}0.053 \\
(0.157) \\
\end{array}$ & $\begin{array}{l}0.456 \\
(0.313) \\
\end{array}$ & $\begin{array}{c}0.121 \\
(0.164) \\
\end{array}$ & $\begin{array}{l}-0.550 \\
(0.418) \\
\end{array}$ & $\begin{array}{l}0.157 \\
(0.133) \\
\end{array}$ \\
\hline Adjusted $\mathrm{R}^{2}$ & 0.51 & 0.51 & 0.40 & 0.37 & 0.38 & 0.38 & 0.48 \\
\hline \multicolumn{8}{|c|}{ Lee model with correction for the endogeneity of vulnerability using the control function method } \\
\hline$I$ & $\begin{array}{l}-1.227^{* *} \\
(0.561)\end{array}$ & $\begin{array}{l}-0.495 \\
(0.435)\end{array}$ & $\begin{array}{l}-0.886^{* * *} \\
(0.186)\end{array}$ & $\begin{array}{l}-0.741 \\
(0.487)\end{array}$ & $\begin{array}{l}-0.355 \\
(0.316)\end{array}$ & $\begin{array}{l}-0.747 * * \\
(0.349)\end{array}$ & $\begin{array}{l}-0.434 \\
(0.338)\end{array}$ \\
\hline$I^{2}$ & $\begin{array}{l}0.077^{* * *} \\
(0.023)\end{array}$ & $\begin{array}{l}0.065^{* *} \\
(0.028)\end{array}$ & $\begin{array}{l}0.046^{* * *} \\
(0.016)\end{array}$ & $\begin{array}{l}0.030 \\
(0.035)\end{array}$ & $\begin{array}{l}0.079^{* * *} \\
(0.023)\end{array}$ & $\begin{array}{l}0.089^{* *} \\
(0.035)\end{array}$ & $\begin{array}{l}0.033^{* *} \\
(0.017)\end{array}$ \\
\hline$\hat{\mu}$ & $\begin{array}{c}0.809 \\
(0.552) \\
\end{array}$ & $\begin{array}{l}0.243 \\
(0.411) \\
\end{array}$ & $\begin{array}{l}0.589^{* * *} \\
(0.174)\end{array}$ & $\begin{array}{l}0.533 \\
(0.486) \\
\end{array}$ & $\begin{array}{l}0.071 \\
(0.319) \\
\end{array}$ & $\begin{array}{c}0.454 \\
(0.324) \\
\end{array}$ & $\begin{array}{l}0.216 \\
(0.329)\end{array}$ \\
\hline$\lambda_{h}$ & $\begin{array}{l}-0.505^{* * *} \\
(0.191)\end{array}$ & $\begin{array}{c}0.152 \\
(0.272)\end{array}$ & $\begin{array}{c}0.045 \\
(0.164)\end{array}$ & $\begin{array}{l}0.410 \\
(0.305)\end{array}$ & $\begin{array}{c}0.127 \\
(0.179)\end{array}$ & $\begin{array}{l}-0.518 \\
(0.409)\end{array}$ & $\begin{array}{c}0.130 \\
(0.139)\end{array}$ \\
\hline Adjusted $\mathrm{R}^{2}$ & 0.51 & 0.51 & 0.40 & 0.37 & 0.38 & 0.38 & 0.48 \\
\hline
\end{tabular}

Source: 1-2-3 Surveys, authors' calculations.

Notes: The standard deviations are bootstrapped (500 replications). Significance of the coefficients: *: at the $10 \%$ level; ** at the $5 \%$ level; *** at the $1 \%$ level.

The control variables are a dummy variable for gender, an education variable (number of years of successfully completed education), potential experience and seniority in the firm, religion (Christian, reference: Muslim), migratory status (rural, urban or foreign migrant, reference: native of the city studied), marital status (conjugal status, reference: widowed, divorced or single), and independent status (self-employed employer or own-account worker versus dependent worker).

The selection identifying variables are the inverse of the dependency ratio (number of employed workers to household size), a dummy variable for whether the individual's father went to primary school and a dummy variable for whether the individual's head of household is a woman.

The control function instruments are the status of the head of household and the institutional sector in which the interviewee's father worked. 
Table 7: Effect of vulnerability on earnings in the informal private sector

\begin{tabular}{|c|c|c|c|c|c|c|c|}
\hline & \multicolumn{7}{|c|}{ Informal sector } \\
\hline & Niamey & Ouagadougou & Dakar & Bamako & Cotonou & Lome & Abidjan \\
\hline \multicolumn{8}{|l|}{ OLS } \\
\hline$I$ & $\begin{array}{l}-0.221 * * * \\
(0.059)\end{array}$ & $\begin{array}{l}-0.309^{* * *} \\
(0.056)\end{array}$ & $\begin{array}{l}-0.251^{* * *} \\
(0.048)\end{array}$ & $\begin{array}{l}-0.128^{* * *} \\
(0.040)\end{array}$ & $\begin{array}{l}-0.164 * * * \\
(0.052)\end{array}$ & $\begin{array}{l}-0.240^{* * *} \\
(0.041)\end{array}$ & $\begin{array}{l}-0.253^{* * *} \\
(0.043)\end{array}$ \\
\hline$I^{2}$ & $\begin{array}{l}0.033^{* *} \\
(0.016)\end{array}$ & $\begin{array}{l}0.066^{* * *} \\
(0.011)\end{array}$ & $\begin{array}{l}0.064^{* * *} \\
(0.012)\end{array}$ & $\begin{array}{l}0.033^{* * *} \\
(0.009)\end{array}$ & $\begin{array}{l}0.041 * * * \\
(0.013)\end{array}$ & $\begin{array}{l}0.066^{* * *} \\
(0.010)\end{array}$ & $\begin{array}{l}0.064^{* * *} \\
(0.010)\end{array}$ \\
\hline Adjusted $\mathrm{R}^{2}$ & 0.49 & 0.23 & 0.33 & 0.25 & 0.27 & 0.28 & 0.24 \\
\hline Obs. & 2,230 & 2,745 & 3,492 & 2,906 & 3,236 & 2,857 & 2,842 \\
\hline \multicolumn{8}{|l|}{ Lee model } \\
\hline$I$ & $\begin{array}{l}-0.310^{* * *} \\
(0.053)\end{array}$ & $\begin{array}{l}-0.252^{* * *} \\
(0.050)\end{array}$ & $\begin{array}{l}-0.128^{* * *} \\
(0.042)\end{array}$ & $\begin{array}{l}-0.163^{* * *} \\
(0.055)\end{array}$ & $\begin{array}{l}-0.242^{* * *} \\
(0.042)\end{array}$ & $\begin{array}{l}-0.256^{* * *} \\
(0.041)\end{array}$ & $\begin{array}{l}-0.157 * * * \\
(0.041)\end{array}$ \\
\hline$I^{2}$ & $\begin{array}{l}0.066^{* * *} \\
(0.011)\end{array}$ & $\begin{array}{l}0.065^{* * *} \\
(0.012)\end{array}$ & $\begin{array}{l}0.033^{* * *} \\
(0.009)\end{array}$ & $\begin{array}{l}0.041^{* * *} \\
(0.014)\end{array}$ & $\begin{array}{l}0.066^{* * *} \\
(0.010)\end{array}$ & $\begin{array}{l}0.064^{* * *} \\
(0.009)\end{array}$ & $\begin{array}{l}0.037^{* * *} \\
(0.010)\end{array}$ \\
\hline$\lambda_{h}$ & $\begin{array}{c}0.055 \\
(0.065)\end{array}$ & $\begin{array}{l}-0.051 \\
(0.069)\end{array}$ & $\begin{array}{l}-0.019 \\
(0.055)\end{array}$ & $\begin{array}{l}-0.046 \\
(0.055)\end{array}$ & $\begin{array}{l}0.071 \\
(0.057)\end{array}$ & $\begin{array}{l}0.155^{* *} \\
(0.072)\end{array}$ & $\begin{array}{l}0.182^{* * *} \\
(0.064)\end{array}$ \\
\hline Adjusted $\mathrm{R}^{2}$ & 0.22 & 0.33 & 0.25 & 0.27 & 0.28 & 0.24 & 0.26 \\
\hline \multicolumn{8}{|c|}{ Lee model with correction for the endogeneity of vulnerability using the control function method } \\
\hline$I$ & $\begin{array}{l}-0.515^{* * *} \\
(0.184)\end{array}$ & $\begin{array}{l}-0.605^{* * *} \\
(0.135)\end{array}$ & $\begin{array}{l}-0.119 \\
(0.252)\end{array}$ & $\begin{array}{l}-0.561^{* * *} \\
(0.206)\end{array}$ & $\begin{array}{l}-0.278 \\
(0.339) \\
\end{array}$ & $\begin{array}{l}-1.045^{* * *} \\
(0.251)\end{array}$ & $\begin{array}{l}-0.648^{* * *} \\
(0.184)\end{array}$ \\
\hline$I^{2}$ & $\begin{array}{l}0.066^{* * *} \\
(0.010)\end{array}$ & $\begin{array}{l}0.065^{* * *} \\
(0.011)\end{array}$ & $\begin{array}{l}0.033^{* * *} \\
(0.009) \\
\end{array}$ & $\begin{array}{l}0.041 * * * \\
(0.013) \\
\end{array}$ & $\begin{array}{l}0.066^{* * *} \\
(0.010)\end{array}$ & $\begin{array}{l}0.064^{* * *} \\
(0.009)\end{array}$ & $\begin{array}{l}0.036^{* * *} \\
(0.011)\end{array}$ \\
\hline$\hat{\mu}$ & $\begin{array}{l}0.206 \\
(0.180) \\
\end{array}$ & $\begin{array}{l}0.358^{* * *} \\
(0.127)\end{array}$ & $\begin{array}{l}-0.009 \\
(0.250)\end{array}$ & $\begin{array}{l}0.401^{* *} \\
(0.200)\end{array}$ & $\begin{array}{c}0.036 \\
(0.337) \\
\end{array}$ & $\begin{array}{l}0.793^{* * *} \\
(0.247) \\
\end{array}$ & $\begin{array}{l}0.500^{* * *} \\
(0.183)\end{array}$ \\
\hline$\lambda_{h}$ & $\begin{array}{l}0.047 \\
(0.065) \\
\end{array}$ & $\begin{array}{l}-0.063 \\
(0.065)\end{array}$ & $\begin{array}{l}-0.019 \\
(0.060) \\
\end{array}$ & $\begin{array}{l}-0.053 \\
(0.060)\end{array}$ & $\begin{array}{l}0.070 \\
(0.056) \\
\end{array}$ & $\begin{array}{c}0.088 \\
(0.076)\end{array}$ & $\begin{array}{l}0.157^{* *} \\
(0.064)\end{array}$ \\
\hline Adjusted R2 & 0.22 & 0.33 & 0.25 & 0.27 & 0.28 & 0.24 & 0.26 \\
\hline
\end{tabular}

Source: 1-2-3 Surveys, authors' calculations.

Notes: The standard deviations are bootstrapped (500 replications). Significance of the coefficients: *: at the $10 \%$ level; ** at the $5 \%$ level; *** at the $1 \%$ level.

The control variables are a dummy variable for gender, the number of years of successfully completed education), potential experience and seniority in the firm, religion, migratory status, marital status, and independent status. The selection identifying variables are the inverse of the dependency ratio, a dummy variable for whether the individual's father went to primary school and a dummy variable for whether the individual's head of household is a woman. The control function instruments are the status of the head of household and the institutional sector in which the interviewee's father worked. 
Chart 2a: Average predicted income (Lee model with endogenous vulnerability) by vulnerability intensity (formal private sector)

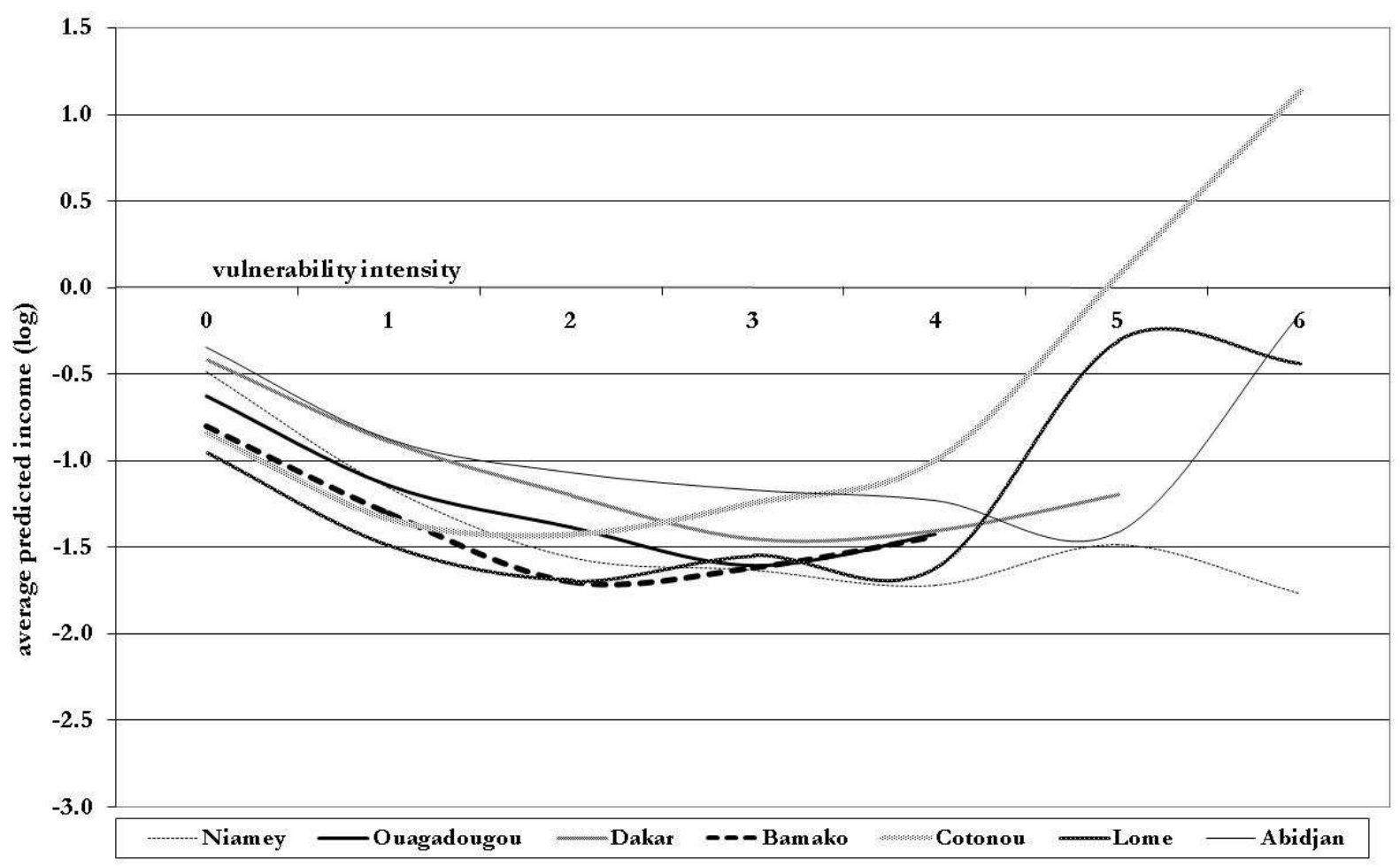

Chart 2b: Average predicted income (Lee model with endogenous vulnerability) by vulnerability intensity (informal private sector)

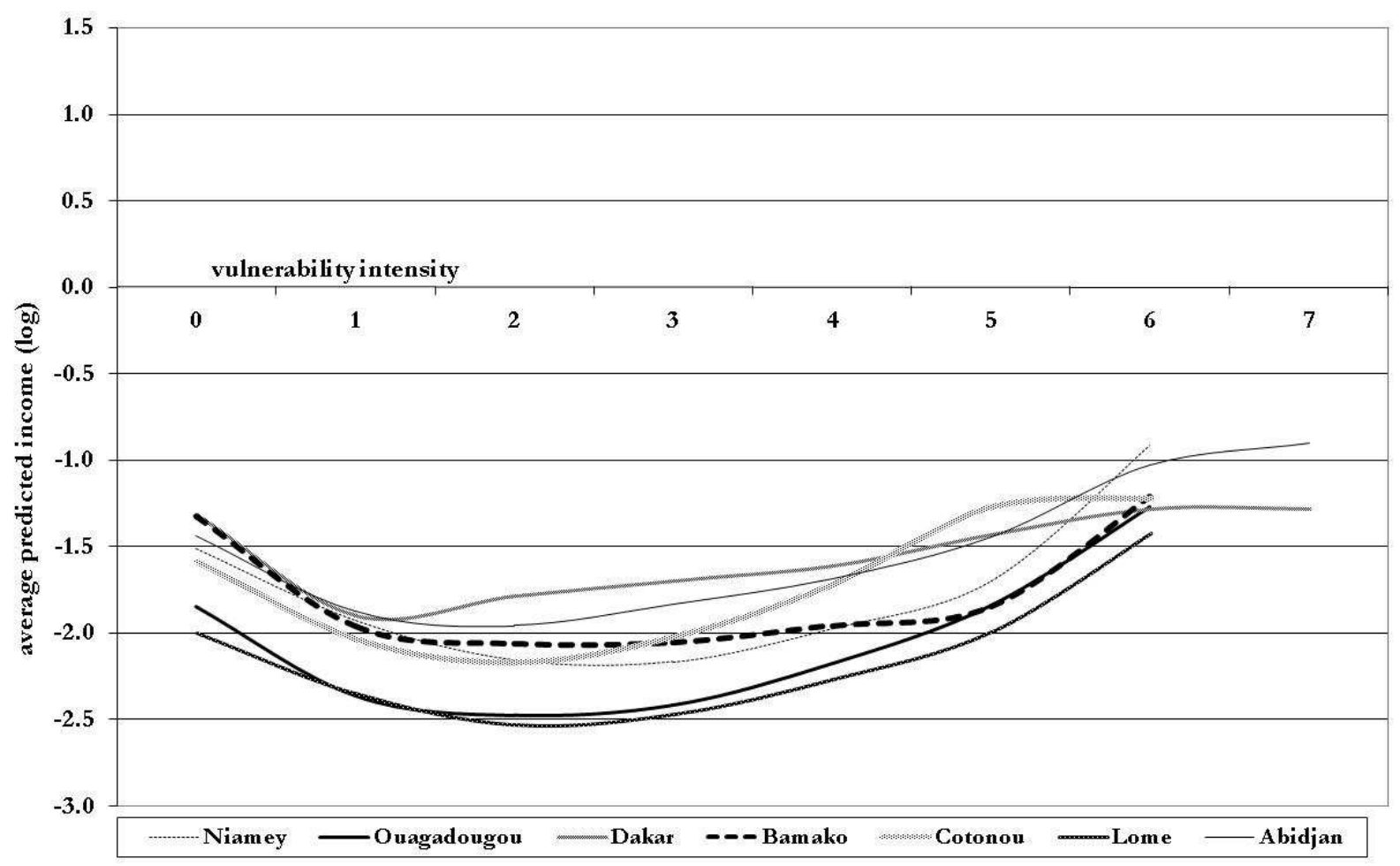


Chart 3a: Marginal effect of vulnerability on income by decile (Formal private sector)

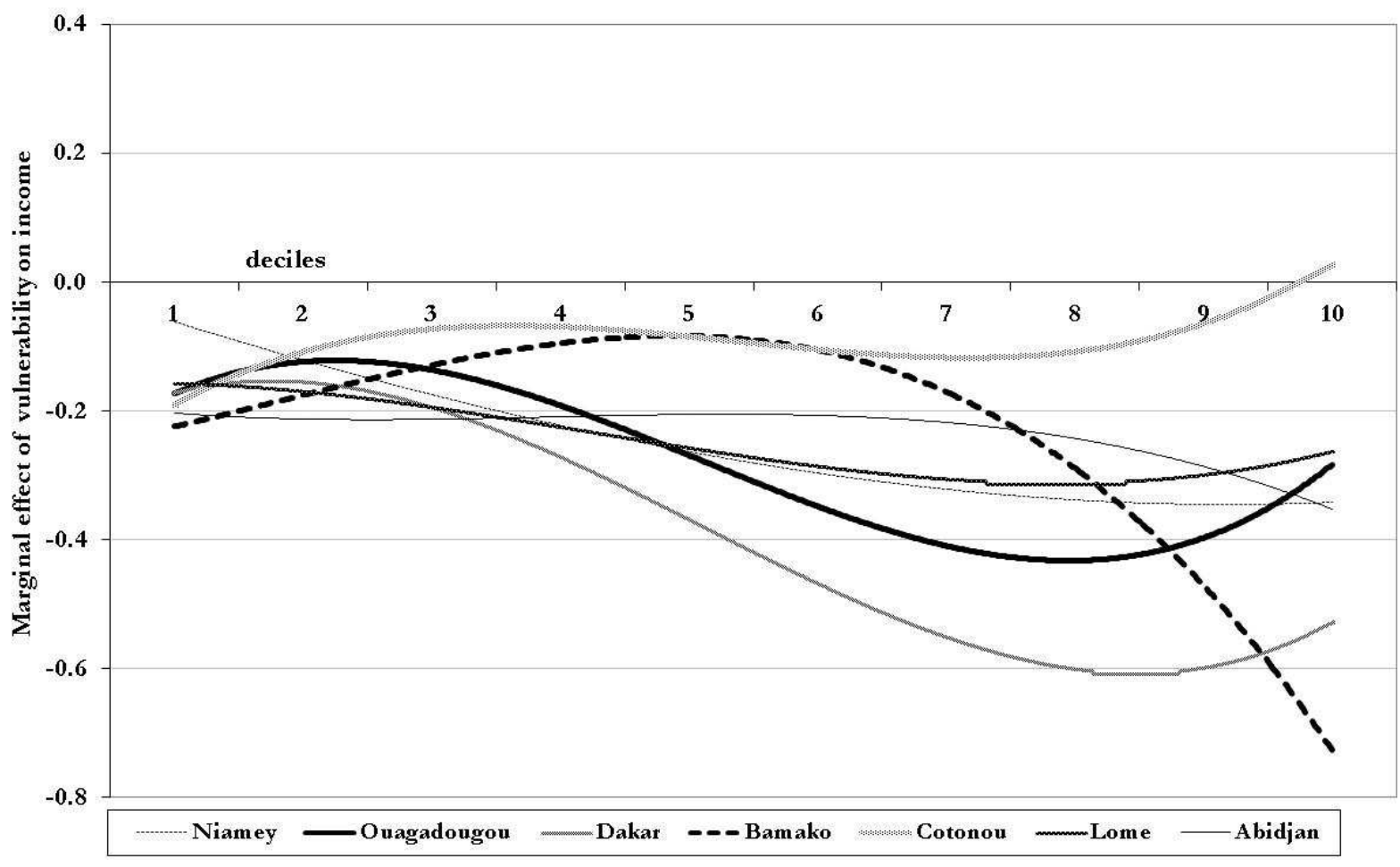

Chart 3b: Marginal effect of vulnerability on income by decile (Informal private sector)

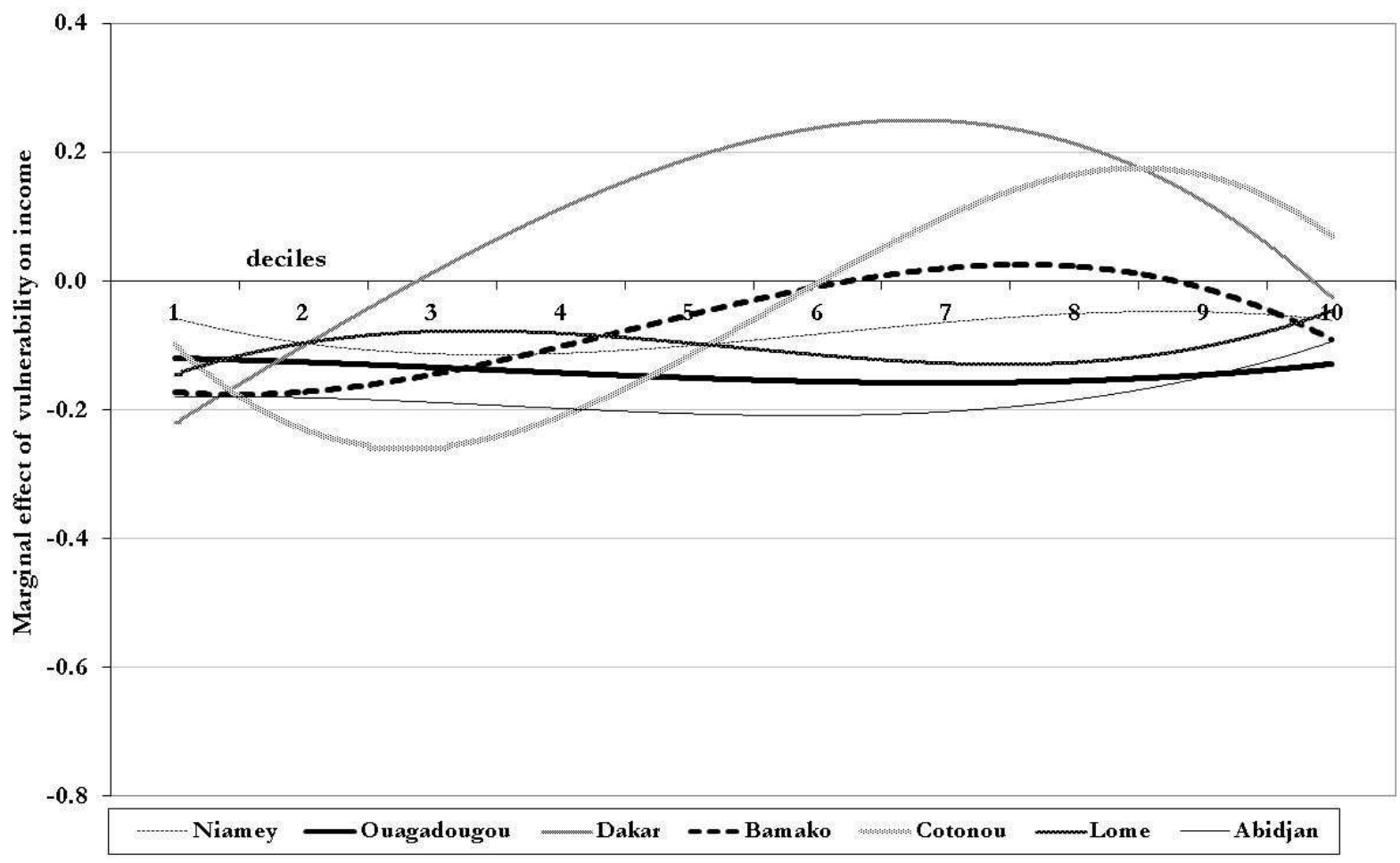


Table 8: Correlations between the principal component analysis axes and the vulnerability criteria

\begin{tabular}{|c|c|c|c|c|}
\hline & Axis 1 & Axis 2 & Axis 3 & Axis 4 \\
\hline \multicolumn{5}{|c|}{ Dependent } \\
\hline \multicolumn{5}{|l|}{ Contributions of the variables to the axes } \\
\hline Contractual insecurity & $70.67 * * *$ & $09.58^{* * *}$ & $06.84^{* * *}$ & $05.74 * * *$ \\
\hline Adverse working conditions & $68.17 * * *$ & -00.94 & 00.29 & 00.52 \\
\hline Casual labour & $53.24 * * *$ & $03.54 * * *$ & $60.34 * * *$ & $03.28^{* * *}$ \\
\hline Unstable remuneration & $76.43 * * *$ & -01.17 & $27.12^{* * *}$ & -00.35 \\
\hline Visible underemployment & $12.27 * * *$ & $03.76^{* * *}$ & $89.04 * * *$ & $-02.10^{* *}$ \\
\hline Working a second vulnerable job & $02.86^{* * *}$ & 01.02 & -01.27 & $99.69 * * *$ \\
\hline Employment instability & 00.20 & $76.96 * * *$ & $-02.79 * * *$ & $-04.11 * * *$ \\
\hline Unwanted job & $05.63^{* * *}$ & $75.00 * * *$ & $10.33 * * *$ & $06.00 * * *$ \\
\hline Explained variance (\%) & 22.19 & 14.53 & 14.33 & 12.52 \\
\hline \multicolumn{5}{|c|}{ Independent } \\
\hline \multicolumn{5}{|l|}{ Contributions of the variables to the axes } \\
\hline Independent, no employees & 00.39 & $-05.39 * * *$ & $75.61 * * *$ & $-06.47 * * *$ \\
\hline Adverse working conditions & $01.33^{*}$ & $26.99 * * *$ & $70.27 * * *$ & $13.77 * * *$ \\
\hline Casual labour & $03.03 * * *$ & $74.95 * * *$ & $13.84 * * *$ & $01.59 * *$ \\
\hline Unstable remuneration & $-05.13^{* * *}$ & $57.96 * * *$ & $-28.91 * * *$ & $04.24 * * *$ \\
\hline Visible underemployment & $12.30^{* * *}$ & $58.23 * * *$ & $28.13^{* * *}$ & $-20.60^{* * *}$ \\
\hline Working a second vulnerable job & 01.29 & $-02.38^{* * *}$ & 00.74 & $97.24 * * *$ \\
\hline Employment instability & $82.75^{* * *}$ & -00.92 & 01.08 & $01.86^{* *}$ \\
\hline Unwanted job & $82.55^{* * *}$ & $07.50^{* * *}$ & $02.52^{* * *}$ & 00.58 \\
\hline Explained variance (\%) & 17.27 & 16.29 & 15.43 & 12.66 \\
\hline
\end{tabular}

Source: 1-2-3 Surveys, authors' calculations. 
Table 9: Effects of the vulnerability axes on earnings in the formal private sector (Lee model)

\begin{tabular}{|c|c|c|c|c|c|c|c|}
\hline & \multicolumn{7}{|c|}{ Formal private sector } \\
\hline & Niamey & Ouagadougou & Dakar & Bamako & Cotonou & Lome & Abidjan \\
\hline $\begin{array}{l}\text { Axis } 1 \text { - Dependent workers: } \\
\text { Contractual insecurity, casual employment and adverse } \\
\text { working conditions }\end{array}$ & $\begin{array}{l}-0.205^{* * *} \\
(0.034)\end{array}$ & $\begin{array}{l}-0.129 * * * \\
(0.043)\end{array}$ & $\begin{array}{l}-0.181^{* * *} \\
(0.023)\end{array}$ & $\begin{array}{l}-0.130^{* * *} \\
(0.045)\end{array}$ & $\begin{array}{l}-0.137 * * * \\
(0.037)\end{array}$ & $\begin{array}{l}-0.186 * * * \\
(0.062)\end{array}$ & $\begin{array}{l}-0.179 * * * \\
(0.030)\end{array}$ \\
\hline $\begin{array}{l}\text { Axis } 2 \text { - Dependent workers: } \\
\text { Subsistence job }\end{array}$ & $\begin{array}{l}-0.067 * * \\
(0.030)\end{array}$ & $\begin{array}{l}0.006 \\
(0.030)\end{array}$ & $\begin{array}{l}-0.023 \\
(0.028)\end{array}$ & $\begin{array}{l}-0.070 * * \\
(0.029)\end{array}$ & $\begin{array}{l}-0.006 \\
(0.025)\end{array}$ & $\begin{array}{l}-0.018 \\
(0.035)\end{array}$ & $\begin{array}{l}-0.047 * * * \\
(0.017)\end{array}$ \\
\hline $\begin{array}{l}\text { Axis } 3 \text { - Dependent workers: } \\
\text { Underemployment }\end{array}$ & $\begin{array}{l}0.121 * * * \\
(0.041)\end{array}$ & $\begin{array}{l}0.137 * * * \\
(0.037)\end{array}$ & $\begin{array}{l}0.031 \\
(0.021)\end{array}$ & $\begin{array}{l}0.079 * * \\
(0.037)\end{array}$ & $\begin{array}{l}0.183^{* * *} \\
(0.044)\end{array}$ & $\begin{array}{l}0.260^{* * *} \\
(0.064)\end{array}$ & $\begin{array}{l}0.127^{* * *} \\
(0.030)\end{array}$ \\
\hline $\begin{array}{l}\text { Axis } 4 \text { - Dependent workers: } \\
\text { Working a second highly vulnerable job }\end{array}$ & $\begin{array}{l}-0.023 \\
(0.224)\end{array}$ & $\begin{array}{l}-0.070 \\
(0.210)\end{array}$ & $\begin{array}{l}0.003 \\
(0.026)\end{array}$ & $\begin{array}{l}-0.053 \\
(0.043)\end{array}$ & $\begin{array}{l}-0.033 \\
(0.023)\end{array}$ & $\begin{array}{l}0.051 \\
(0.037)\end{array}$ & $\begin{array}{l}-0.096 \\
(0.374)\end{array}$ \\
\hline $\begin{array}{l}\text { Axis } 1 \text { - Independent workers: } \\
\text { Subsistence job }\end{array}$ & $\begin{array}{l}0.289 \\
(0.958)\end{array}$ & $\begin{array}{l}-0.273 \\
(24.789)\end{array}$ & $\begin{array}{l}-0.164 \\
(0.125)\end{array}$ & $\begin{array}{l}0.074 \\
(2.058)\end{array}$ & $\begin{array}{l}0.063 \\
(0.193)\end{array}$ & $\begin{array}{l}-0.142 \\
(0.278)\end{array}$ & $\begin{array}{l}-0.340 \\
(2.750)\end{array}$ \\
\hline $\begin{array}{l}\text { Axis } 2 \text { - Independent workers: } \\
\text { Underemployment }\end{array}$ & $\begin{array}{l}0.048 \\
(0.196)\end{array}$ & $\begin{array}{l}0.266 \\
(0.199)\end{array}$ & $\begin{array}{l}-0.031 \\
(0.087)\end{array}$ & $\begin{array}{l}-0.317 \\
(0.288)\end{array}$ & $\begin{array}{l}0.353^{*} \\
(0.182)\end{array}$ & $\begin{array}{l}0.170 \\
(1.229)\end{array}$ & $\begin{array}{l}-0.006 \\
(0.271)\end{array}$ \\
\hline $\begin{array}{l}\text { Axis } 3 \text { - Independent workers: } \\
\text { No employees and adverse working conditions }\end{array}$ & $\begin{array}{l}-0.235 \\
(0.216)\end{array}$ & $\begin{array}{l}0.033 \\
(0.570)\end{array}$ & $\begin{array}{l}-0.103 \\
(0.121)\end{array}$ & $\begin{array}{l}-0.077 \\
(0.180)\end{array}$ & $\begin{array}{l}-0.279 * * \\
(0.119)\end{array}$ & $\begin{array}{l}0.068 \\
(1.387)\end{array}$ & $\begin{array}{l}-0.276 \\
(0.182)\end{array}$ \\
\hline $\begin{array}{l}\text { Axis } 4 \text { - Independent workers: } \\
\text { Working a second highly vulnerable job }\end{array}$ & $\begin{array}{l}-0.026 \\
(0.753)\end{array}$ & $\begin{array}{l}-2.585 \\
(2.208)\end{array}$ & $\begin{array}{l}-0.138 \\
(0.491)\end{array}$ & $\begin{array}{l}-0.577 \\
(1.007)\end{array}$ & $\begin{array}{c}0.147 \\
(0.583)\end{array}$ & $\begin{array}{l}-1.275 \\
(2.316)\end{array}$ & $\begin{array}{l}-2.306^{* *} \\
(0.935)\end{array}$ \\
\hline Selection correction & $\begin{array}{l}-0.400^{* *} \\
(0.185)\end{array}$ & $\begin{array}{l}0.196 \\
(0.216)\end{array}$ & $\begin{array}{l}0.048 \\
(0.164)\end{array}$ & $\begin{array}{l}0.475 \\
(0.306)\end{array}$ & $\begin{array}{l}0.046 \\
(0.163)\end{array}$ & $\begin{array}{l}-0.629 \\
(0.399)\end{array}$ & $\begin{array}{c}0.078 \\
(0.127)\end{array}$ \\
\hline Observations & 409 & 336 & 950 & 452 & 509 & 302 & 825 \\
\hline Adjusted $\mathrm{R}^{2}$ & 0.53 & 0.55 & 0.40 & 0.37 & 0.41 & 0.44 & 0.51 \\
\hline
\end{tabular}

Source: 1-2-3 Surveys, authors' calculations.

Notes: The standard deviations are bootstrapped (500 replications). Significance of the coefficients: *: at the $10 \%$ level; ** at the $5 \%$ level; *** at the $1 \%$ level.

The control variables are a dummy variable for gender, an education variable (number of years of successfully completed education), potential experience and seniority in the firm, religion, migratory status, marital status, and independent status (self-employed employer or own-account worker versus dependent worker).

The selection identifying variables are the inverse of the dependency ratio (number of employed workers to household size), a dummy variable for whether the individual's

father went to primary school and a dummy variable for whether the individual's head of household is a woman. 
Table 10: Effects of the vulnerability axes on earnings in the informal private sector (Lee model)

\begin{tabular}{|c|c|c|c|c|c|c|c|}
\hline & \multicolumn{7}{|c|}{ Informal private sector } \\
\hline & Niamey & Ouagadougou & Dakar & Bamako & Cotonou & Lome & Abidjan \\
\hline $\begin{array}{l}\text { Axis } 1 \text { - Dependent workers: } \\
\text { Contractual insecurity, casual employment and adverse } \\
\text { working conditions }\end{array}$ & $\begin{array}{l}-0.080^{* * *} \\
(0.026)\end{array}$ & $\begin{array}{l}-0.107^{* * *} \\
(0.023)\end{array}$ & $\begin{array}{l}-0.059 * * * \\
(0.020)\end{array}$ & $\begin{array}{l}-0.040 \\
(0.030)\end{array}$ & $\begin{array}{l}-0.064 * * \\
(0.029)\end{array}$ & $\begin{array}{l}-0.088^{* * *} \\
(0.030)\end{array}$ & $\begin{array}{l}-0.104 * * * \\
(0.023)\end{array}$ \\
\hline $\begin{array}{l}\text { Axis } 2 \text { - Dependent workers: } \\
\text { Subsistence job }\end{array}$ & $\begin{array}{l}-0.019 \\
(0.028)\end{array}$ & $\begin{array}{l}0.018 \\
(0.035)\end{array}$ & $\begin{array}{l}-0.014 \\
(0.022)\end{array}$ & $\begin{array}{l}0.006 \\
(0.048)\end{array}$ & $\begin{array}{l}-0.006 \\
(0.035)\end{array}$ & $\begin{array}{l}-0.025 \\
(0.024)\end{array}$ & $\begin{array}{l}-0.019 \\
(0.020)\end{array}$ \\
\hline $\begin{array}{l}\text { Axis } 3 \text { - Dependent workers: } \\
\text { Underemployment }\end{array}$ & $\begin{array}{l}0.164 * * * \\
(0.031)\end{array}$ & $\begin{array}{l}0.165^{* * *} \\
(0.026)\end{array}$ & $\begin{array}{l}0.161^{* * *} \\
(0.029)\end{array}$ & $\begin{array}{l}0.134 * * * \\
(0.033)\end{array}$ & $\begin{array}{l}0.078^{* *} \\
(0.031)\end{array}$ & $\begin{array}{l}0.168^{* * *} \\
(0.025)\end{array}$ & $\begin{array}{l}0.165^{* * *} \\
(0.024)\end{array}$ \\
\hline $\begin{array}{l}\text { Axis } 4 \text { - Dependent workers: } \\
\text { Working a second highly vulnerable job }\end{array}$ & $\begin{array}{l}0.011 \\
(0.028)\end{array}$ & $\begin{array}{l}-0.027 \\
(0.022)\end{array}$ & $\begin{array}{l}-0.076 \\
(0.083)\end{array}$ & $\begin{array}{l}-0.028 \\
(0.022)\end{array}$ & $\begin{array}{l}-0.051 * * * \\
(0.015)\end{array}$ & $\begin{array}{l}-0.016 \\
(0.033)\end{array}$ & $\begin{array}{l}-0.010 \\
(0.022)\end{array}$ \\
\hline $\begin{array}{l}\text { Axis } 1 \text { - Independent workers: } \\
\text { Subsistence job }\end{array}$ & $\begin{array}{l}-0.021 \\
(0.020)\end{array}$ & $\begin{array}{l}0.034^{*} \\
(0.019)\end{array}$ & $\begin{array}{l}-0.009 \\
(0.024)\end{array}$ & $\begin{array}{l}-0.045^{* *} \\
(0.019)\end{array}$ & $\begin{array}{l}0.005 \\
(0.015)\end{array}$ & $\begin{array}{l}-0.003 \\
(0.012)\end{array}$ & $\begin{array}{l}-0.011 \\
(0.014)\end{array}$ \\
\hline $\begin{array}{l}\text { Axis } 2 \text { - Independent workers: } \\
\text { Underemployment }\end{array}$ & $\begin{array}{l}0.062^{* * *} \\
(0.015)\end{array}$ & $\begin{array}{l}0.177 * * * \\
(0.020)\end{array}$ & $\begin{array}{l}0.084^{* * *} \\
(0.014)\end{array}$ & $\begin{array}{l}0.137 * * * \\
(0.022)\end{array}$ & $\begin{array}{l}0.177 * * * \\
(0.019)\end{array}$ & $\begin{array}{l}0.165^{* * *} \\
(0.020)\end{array}$ & $\begin{array}{l}0.195^{* * *} \\
(0.030)\end{array}$ \\
\hline $\begin{array}{l}\text { Axis } 3 \text { - Independent workers: } \\
\text { No employees and adverse working conditions }\end{array}$ & $\begin{array}{l}-0.055^{* * *} \\
(0.019)\end{array}$ & $\begin{array}{l}-0.108^{* * *} \\
(0.018)\end{array}$ & $\begin{array}{l}-0.026 \\
(0.017)\end{array}$ & $\begin{array}{l}-0.083 * * * \\
(0.020)\end{array}$ & $\begin{array}{l}-0.079 * * * \\
(0.016)\end{array}$ & $\begin{array}{l}-0.089 * * * \\
(0.018)\end{array}$ & $\begin{array}{l}-0.098^{* * *} \\
(0.021)\end{array}$ \\
\hline $\begin{array}{l}\text { Axis } 4 \text { - Independent workers: } \\
\text { Working a second highly vulnerable job }\end{array}$ & $\begin{array}{l}-0.050^{*} \\
(0.029)\end{array}$ & $\begin{array}{l}-0.018 \\
(0.021)\end{array}$ & $\begin{array}{l}-0.082 * * * \\
(0.022)\end{array}$ & $\begin{array}{l}-0.052^{* * *} \\
(0.017)\end{array}$ & $\begin{array}{l}-0.040^{* * *} \\
(0.013)\end{array}$ & $\begin{array}{l}-0.050^{* * *} \\
(0.015)\end{array}$ & $\begin{array}{l}-0.112^{* * *} \\
(0.034)\end{array}$ \\
\hline Selection correction & $\begin{array}{l}0.051 \\
(0.060)\end{array}$ & $\begin{array}{l}-0.021 \\
(0.060)\end{array}$ & $\begin{array}{l}0.004 \\
(0.056)\end{array}$ & $\begin{array}{l}-0.027 \\
(0.057)\end{array}$ & $\begin{array}{l}0.077 \\
(0.052)\end{array}$ & $\begin{array}{l}0.153^{* *} \\
(0.077)\end{array}$ & $\begin{array}{l}0.181 * * * \\
(0.064)\end{array}$ \\
\hline Observations & 2,230 & 2,745 & 3,492 & 2,906 & 3,236 & 2,857 & 2,842 \\
\hline Adjusted $\mathrm{R}^{2}$ & 0.23 & 0.35 & -0.26 & 0.29 & 0.30 & 0.26 & 0.28 \\
\hline
\end{tabular}

Source: 1-2-3 Surveys, authors' calculations.

Notes: The standard deviations are bootstrapped (500 replications). Significance of the coefficients: *: at the $10 \%$ level; ** at the $5 \%$ level; *** at the $1 \%$ level.

The control variables are a dummy variable for gender, an education variable (number of years of successfully completed education), potential experience and seniority in the firm, religion, migratory status, marital status, and independent status (self-employed employer or own-account worker versus dependent worker).

The selection identifying variables are the inverse of the dependency ratio (number of employed workers to household size), a dummy variable for whether the individual's father went to primary school and a dummy variable for whether the individual's head of household is a woman. 


\section{References}

Akerlof, G., Yellen, J. (1990), “The fair wage-effort hypothesis and unemployment", Quarterly Journal of Economics, 105, pp. 255-238.

Bockerman, P., Ilmakunnas, P. (2006), "Do job disamenities raise wage or ruin job satisfaction?”, International Journal of Manpower, 27(3), pp. 290-302.

Bourguignon, F., Fournier, M., Gurgand, M. (2007), "Selection bias corrections based on the multinomial logit model: Monte-Carlo comparisons", Journal of Economic Surveys, 21(1), pp. 174-205.

Brilleau, A., Ouedraogo, E., Roubaud, F. (2005), "L'enquête 1-2-3 dans les principales agglomérations de l'UEMOA: La consolidation d'une méthode", Stateco, 99, pp. 15-19.

Brown, C. (1980), "Equalizing differences in the labor market", The Quarterly Journal of Economics, 94(1), pp. 113-134

Burdett, K., Mortensen, D.T. (1998), "Wage differentials, employer size and unemployment", International Economic Review, 39, pp. 257-273.

Card, D. (2001), "Estimating the return to schooling: Progress on some persistent econometric problems", Econometrica, 69, pp. 1127-1160.

Cheli, B., Lemmi, A., (1995), "A 'totally' fuzzy and relative approach to the measurement of poverty”, Economic Notes, 94, pp. 115-34.

Clark, A., Senik, C. (2006), 'The (unexpected) structure of 'rents' on the french and british labour markets", Journal of Socioeconomics, 35, pp. 180-196.

Daniel, C., Sofer, C., (1998), "Bargaining, compensating wage differentials, and dualism of the labor market: Theory and evidence for France", Journal of Labor Economics, 16(3), pp. 546575.

Dubois, J.-L., Rousseau, S. (2001), "Reinforcing household's capabilities as a way to reduce vulnerability and prevent poverty in equitable terms", Conference Justice and Poverty: Examining Sen's Capability Approach, 5-7 June 2001, Cambridge University.

El Aynaoui, J.-P.K. (1996), "Une investigation du lien pauvreté-marché du travail dans le contexte du Maroc", Région et Développement, 3.

Fernández, R.M., Nordman, C.J. (2009), “Are there pecuniary compensations for working conditions?”, Labour Economics, 16(2), pp. 194-207.

French, M. T., Dunlap, L. J. (1998), “Compensating wage differentials for job stress", Applied Economics, 30, pp. 1067-1075.

Garen, J. (1984), “The returns to schooling: A selectivity bias approach with a continuous choice variable", Econometrica, 52, pp. 1199-1218.

Groot, W., Maassen van den Brink, H. (1998), “The price of stress”, Journal of Economic Psychology, 20, pp. 83-103.

Hwang, H., Mortensen, D.T., Reed, W.R. (1998), "Hedonic wages and labor market search", Journal of Labor Economics, 16(4), pp. 815-847.

Jellal, M., Nordman, C.J., Wolff, F-C. (2008), "Evidence on the glass ceiling effect in France using matched worker-firm data", Applied Economics, 40(24), pp. 3233-3250.

Katz, L. F., (1986), "Efficiency wage theories: A partial evaluation", in Fisher, S. (ed.), NBER Macroeconomics Annual, Cambridge, Mass., MIT Press. 
Kuepie, M., Nordman, C.J., Roubaud, F. (2009), "Education and earnings in urban West Africa", Journal of Comparative Economics, 37(3), pp. 491-515.

Lanfranchi, J., Ohlsson, H., Skalli, A. (2002), "Compensating wage differentials and shift work preferences”, Economics Letters, 74, pp. 393-398.

Lee, L.F., 1983, "Generalized econometric models with selectivity”, Econometrica, 51, pp. 507-512.

Lindbeck, A., Snower, D.J. (1989), The insider-outsider theory of employment and unemployment, Cambridge, MIT Press.

Maloney, W. (2004), “Informality revisited”, World Development, 32(7), pp. 1159-1178.

Magnani, E. (2002), "Product market volatility and the adjustment of earning to risk", Industrial Relations, 41, pp. 304-328.

Manning, A. (2003), Monopsony in motion: imperfect competition in labor markets, Princeton University Press.

Mortensen, D.T. (2003), Wage dispersion: why are similar workers paid differently?, Cambridge, MA: MIT Press.

Murphy, K.M., Topel R. (1987), "Unemployment, risk and earnings: Testing for equalizing wage differences in the labor market", in Lang, K. and Leonard, J. (eds.), Unemployment and the Structure of Labor Markets, Basil Blackwell.

Pagès, N. (2003), "Hétérogénéité des systèmes d'emploi urbain et vulnérabilité au travail : application aux entreprises et aux petites unités productives en Côte d'Ivoire", 3rd Conference "Approche des Capacités: d'un développement viable à une liberté durable », University of Pavia, Italy, September 8-10.

Pagès, N. (2005), "Hétérogénéité du système d'emploi et développement : Une application aux entreprises et aux petites unités productives urbaines en Côte d'Ivoire", PhD Thesis, Université Paris X-Nanterre.

Pissarides, C. (2000), Equilibrium unemployment theory, MIT Press, Cambridge, MA, $2^{\text {nd }}$ edition.

Poggi, A. (2007), "Do satisfactory working conditions contribute to explaining earning differentials in Italy? A panel data approach", Labour, 21(4/5), pp. 713-733.

Qizilbash, M. (2003), "Vague language and precise measurement: The case of poverty", Journal of Economic Methodology, 10, pp. 41-58.

Qizilbash, M. (2006), "Philosophical accounts of vagueness, fuzzy poverty measures and multidimensionality", in Lemmi, A. and Betti, G. (eds.), Furay Set Approach to Multidimensional Poverty Measurement, Chapter 1, pp. 9-28, Springer.

World Bank Annual Report (2000).

Rosen, S. (1986) "The theory of equalising differences", in Handbook of Labor Economics, O. Ashenfelter and R. Layard (eds.), Chapter 12, Vol. 1, Elsevier Science Publishers.

Sen, A. K. (1992), Inequality reexamined, Oxford University Press.

Sen, A.-K. (1999), Development as freedom, Alferd Knopf. Inc.

System of National Account (1993), OECD, World Bank, European Commission, United Nations and International Monetary Funds, published by the Statistical Division of the United Nations.

Wilson, F., Ramphele, M., (1989), Uprooting poverty: The Suth African challenge, New York and London: Norton. 
Wooldridge, J.M. (2002), "Unobserved heterogeneity and estimation of average partial effects", Michigan State University Working Paper. 